\title{
On the Diatom Flora in Interglacial Kieselguhr at Hollerup in East Jutland
}

\author{
By \\ Niels Foged
}

I kommission hos

C. A. REITZELS FORLAG (JØRGEN SANDAL)

KØBENHAVN 1962 


\section{On the Diatom Flora in Interglacial Kieselguhr at Hollerup in East Jutland}

By

Niels Foged

I kommission hos C. A. REITZELS FORLAG (JØRGEN SANDAL) KøBENHAVN 1962 
ANDELSBOGTRYKKERIET I ODENSE 


\begin{abstract}
In 38 samples of diatoms from the interglacial kieselguhr deposits at Hollerup in East Jutland, the presence of 355 different forms of diatoms was established, including 11 nov. spec., and 1 nov. var.

$\mathrm{pH}$ and halobion spectra show that sedimentation occurred in a nutritious fresh water area with $\mathrm{pH}$ abt. 7.0.

The proportion of Centrales to Pennales indicates that during depositing of the lowest layers, there have been considerable quantities of free water in the lake, which was afterwards filled up with a widely distributed reedswamp vegetation. This vegetation has served as a medium for the epiphytic diatoms found to be predominant in the samples from the upper layers of the deposit.
\end{abstract}


I offer my respectful thanks to the Geological SuRveY of DENMARK for publishing this treatise in the publications of the institute, to The Danish State Research Foundation for defraying the costs of printing, and to the RASK-ØRSTED FOUNDATION for grants for the translation.

For latinizing of diagnoses I am indebted to Mr. TyGE Christensen, M. Sc., and for translation into English to Mrs. Mabel Dyrup.

Odense, December 1961.

NiELS Foged 


\section{CONTENTS}

1. Introduction . . . . . . . . . . . . 7

2. Material from Hollerup kieselguhr deposit . . . . . . . . 8

3. Spectra and Quotients . . . . . . . . . . 10

4. Observations concerning diatoms shown in plates I-V . . 13

5. Table of the diatoms found in Danish interglacial kieselguhr . 27

6. Literature . . . . . . . . . . . . . . 39

7. Plates ................... 41 


\section{INTRODUCTION}

ØSTRUP 1899 established the presence of about 160 different forms of diatoms in the interglacial deposits of Jutland (at Hollerup, at Vejle, in the cliffs at Trelde and at Fredericia). He showed that these kieselguhr deposits were formed in fresh water, under climatic conditions very similar to those prevailing in Denmark at the present time.

MøLler 1943 has described the flora of a kieselguhr deposit in the neighbourhood of Lundeborg in East Funen, and FogED 1954 b has investigated another kieselguhr deposit at Knarreborg about $1.5 \mathrm{~km}$ south of Lundeborg. The floras of these two deposits are closely related fresh water floras possibly from the last interglacial period. The diatom flora of an interglacial kieselguhr deposit at Vejlby, Rands fjord, near Fredericia in East Jutland proved to be quite rich in species, as was also the case in the flora of the Knarreborg deposits (Foged $1960 \mathrm{a}$ ), the number of forms observed here being about 235 (at Knarreborg about 200). A considerable number of these forms have not previously been identified in interglacial kieselguhr in Denmark.

In the analyses of the Hollerup kieselguhr flora given here, 355 different diatom forms were found, and here again, large numbers of them have not previously been identified in Danish interglacial microflora. The total number of fresh water diatom forms found in Danish interglacial kieselguhr is therefore about 465 . 


\section{MATERIAL FROM HOLLERUP KIESELGUHR DEPOSIT}

11th August 1949, 38 samples were taken from sections of a pit where quarrying of kieselguhr was taking place. The samples Nos. 1-18 were taken almost vertically one above the other in a main section about $8 \mathrm{~m}$ high, comprising 3 formations or strata.

Nos. 1-6 are from stratum 1 at the bottom of the pit. No. 1 was taken at the foot of the stratum $(0 \mathrm{~cm})$ i. e. right at the bottom of the pit, and the following at heights of 50,100, 150, 200 and $270 \mathrm{cms}$ above the bottom face.

The sediment in stratum 1 was almost black, and its content of organic material so great that the clay could burn after being dried in air. Nos. 1-4 showed strong formation of air on treatment with $\mathrm{HCl}$, whereas none of the other samples from the clay pit gave this result when treated with $\mathrm{HCl}$. In stratum 2, samples Nos. 7-13 were taken at heights of 320, 370, 420, 428, 432,480 , and $520 \mathrm{cms}$ above the bottom face.

The kieselguhr in Nos. 7-9 was dark brown in colour. At about $430 \mathrm{cms}$, there was a sharp change between a lower dark-brown coloured series of layers and an upper pale gray series.

From the uppermost stratum (3) samples Nos. 14-18 were taken at heights of $580,630,680,730$ and $780 \mathrm{cms}$ above the bottom face of the pit. Nos. 14-17 consisted of very pale kieselguhr, whereas No. 18 was somewhat darker than the underlying layers.

Samples Nos. 19-22 were taken from the most westerly part of the pit in a section exposed just below the diluvial sediments forming the surface. No. 19 is the sample from the lowest part of the section, No. 22 was taken from just below the glacial fluvial sediments. The samples were taken vertically at intervals of about $50 \mathrm{cms}$. The kieselguhr here was almost chocolate brown in colour and of rather loose texture.

Samples Nos. 23-38 were taken from a smaller section (about $2 \mathrm{~m}$ high) at the eastern end of the pit. The upper face of this section formed the surface of the earth, and there seemed to be no signs of any removal of an overlying layer. The texture here was more varied than in the other parts of the pit, and the samples were therefore taken at smaller intervals:

No. 23. $0 \mathrm{~cm}$. (lower edge of section). Pale gray clay, indistinct striation.

- $24.8 \mathrm{~cm}$. (above lower edge of section). Reddish brown layer with distinct striation. 
No. 25. $15 \mathrm{~cm}$. Dark gray to grayish black clay. Rather more distinct striation.

- 26. $27 \mathrm{~cm}$. Alternating pale and dark layers. The individual layers from $0.5 \mathrm{~mm}$ to $5-6 \mathrm{~mm}$ thick.

- 27. $45 \mathrm{~cm}$. Alternating pale and dark layers (as in No. 26). The dark layers generally thinner than the pale ones.

- 28. $68 \mathrm{~cm}$. Striation as in No. 27 but somewhat coarser.

- 29. $72 \mathrm{~cm}$. Still rather dense striation. Colour somewhat darker than in the layers below.

- 30. $98 \mathrm{~cm}$. Paler than the layers above and below.

- 31. $108 \mathrm{~cm}$. The dense striation ceases at $104 \mathrm{~cm}$. After this the striation is indistinct and coarser.

A somewhat darker type of clay.

- 32. $120 \mathrm{~cm}$. Still darker type of clay.

- 33. $122 \mathrm{~cm}$.

- $34.132 \mathrm{~cm}$. Indistinct striation. Colour becomes lighter again.

- $35.152 \mathrm{~cm}$. Irregular striped and spotted type of clay. Dark colour.

- $36.177 \mathrm{~cm}$. Rather more distinct but coarse striation, lighter colour, sandy.

This last sample was taken $8 \mathrm{~cm}$ below surface of the earth.

Samples Nos. 37 and 38 were from finely striated section on the wall of the pit halfway between the main section and section Nos. 23-36. No. 37 consisted of dark chocolate-coloured sediment, and No. 38 was dark kieselguhr with some Vivianite. They were both from the uppermost part of the section.

Diatoms were found in all the samples. The valves seem to be, on the whole, better preserved than in kieselguhr deposits further south in Denmark. 


\section{SPECTRA AND QUOTIENTS}

The $\mathrm{pH}$ and halobion spectra have been calculated (tables 1 and 2) for each sample of the series, beginning with No. 1 and ending with No. 36. Arrangement and calculation as in Foged 1954 a.

In the $\mathrm{pH}$ spectra, alkaliphilous forms were predominant in all the samples, with regard both to the number of forms and to the number of valves. In samples Nos. 6, 21, 26, and 31, comparatively many valves of indifferent forms were found. Acidophilous types were extremely rare, and none of the observed forms have been met with in a valve count up to 500. It can be rightly concluded, from the $\mathrm{pH}$ spectra, that during the diatomaceous sedimentation the reaction in the lake bed has been chiefly alkaline, periodically with a tendency towards the neutral reaction.

There is still more uniformity in the halobion spectra here than in the Vejlby section. Practically all the forms identified must be regarded as oligohalobousindifferent fresh water forms. Actual salt-repelling or salt-requiring forms are extremely rare, and the few valves found that could be classed under these two categories, could be adventive and have originated from localities with different environment.

The two spectra shown here reveal no change of environment during sedimentation. On the other hand, the quotient Centrales:Pennales indicates that at a certain period something must have occurred in the lake bed. From table 3 in which the quotient $\mathrm{C}: \mathrm{P}$ is calculated on the basis of the valve count, we notice a remarkable fall with regard to the quotients, when we compare those of the samples Nos. 1 and 6 which have quotients 1.41 and 0.91 , with those of the remainder of the series, where the quotients lie between 0.06 and 0.03 . This indicates that whereas the valves of the centric forms are very predominant in the earliest (lowest) formation, they are practically nonexistent in the rest of the section. This may indicate that sedimentation began in a large, and rather deep, fresh water basin. With the filling up or draining off of the lake basin, the water level changed, so that the bottom vegetation on the bed of the lake, and reed swamp have formed an excellent medium for epiphytic forms and facultative plankton species, whereas the actual plankton forms which embrace the centric forms, have had their potentiality strongly reduced.

In table 4, C : P quotient is calculated on the basis of the number of diatom species met with in a valve count up to 500 in the sample. These numbers 
and quotients do not show as distinctly as table 3, the almost certain change that has taken place in the flora between No. 6 and No. 11. From the table, however, it can be seen that the number of centric forms is decidedly lower in samples 11-36 than in samples 1-6. It must be emphasised that in the case of the $\mathrm{pH}$ and halobion spectra (tables 1 and 2), the quotients were calculated on the basis of the total number of species found in analysing the samples, whereas C: P quotients (table 4) were calculated on the basis of the number of species met with in a valve count of up to 500. This explains the considerably lower number of species here.

Table 1. pH-spectra

\begin{tabular}{|c|c|c|c|c|c|c|c|c|c|}
\hline & $\begin{array}{c}\text { Sample } \\
\text { no. }\end{array}$ & 1 & 6 & 11 & 16 & 21 & 26 & 31 & 36 \\
\hline Acidophilous & \begin{tabular}{|c|} 
species \\
$\%$ \\
\end{tabular} & $\begin{array}{c}0 \\
0.0\end{array}$ & $\begin{array}{c}0 \\
0.0\end{array}$ & $\begin{array}{c}0 \\
0.0\end{array}$ & $\begin{array}{c}1 \\
0.0\end{array}$ & $\begin{array}{c}0 \\
0.0\end{array}$ & $\begin{array}{c}3 \\
0.0\end{array}$ & $\begin{array}{c}0 \\
0.0\end{array}$ & $\begin{array}{c}5 \\
0.0\end{array}$ \\
\hline Indifferent & $\begin{array}{c}\text { species } \\
\% \\
\end{array}$ & $\begin{array}{c}7 \\
8.4 \\
\end{array}$ & $\begin{array}{c}9 \\
3.4 \\
\end{array}$ & $\begin{array}{c}7 \\
3.2 \\
\end{array}$ & $\begin{array}{c}6 \\
18.2 \\
\end{array}$ & $\begin{array}{c}8 \\
20.4 \\
\end{array}$ & $\begin{array}{c}16 \\
17.8 \\
\end{array}$ & $\begin{array}{c}15 \\
39.8 \\
\end{array}$ & $\begin{array}{l}40 \\
6.4 \\
\end{array}$ \\
\hline Alkaliphilous & $\begin{array}{c}\text { species } \\
\%\end{array}$ & $\begin{array}{c}57 \\
89.0\end{array}$ & $\begin{array}{c}53 \\
95.6\end{array}$ & $\begin{array}{c}36 \\
96.8\end{array}$ & $\begin{array}{c}44 \\
81.8\end{array}$ & $\begin{array}{c}43 \\
79.0\end{array}$ & $\begin{array}{c}74 \\
82.0\end{array}$ & $\begin{array}{c}80 \\
60.0\end{array}$ & $\begin{array}{l}118 \\
92.6\end{array}$ \\
\hline$?$ & $\begin{array}{c}\text { species } \\
\%\end{array}$ & $\begin{array}{c}2 \\
2.6 \\
\end{array}$ & $\begin{array}{c}6 \\
1.0 \\
\end{array}$ & $\begin{array}{c}0 \\
0.0\end{array}$ & $\begin{array}{c}1 \\
0.0\end{array}$ & $\begin{array}{c}3 \\
0.6\end{array}$ & $\begin{array}{c}6 \\
0.2 \\
\end{array}$ & $\begin{array}{c}2 \\
0.2 \\
\end{array}$ & $\begin{array}{c}19 \\
1.0\end{array}$ \\
\hline Number of species & & 66 & 68 & 43 & 52 & 54 & 99 & 97 & 182 \\
\hline
\end{tabular}

Table 2. Halobion spectra

\begin{tabular}{|c|c|c|c|c|c|c|c|c|c|}
\hline & $\begin{array}{c}\text { Sample } \\
\text { no. }\end{array}$ & 1 & 6 & 11 & 16 & 21 & 26 & 31 & 36 \\
\hline Halophobous & $\begin{array}{c}\text { species } \\
\% \\
\end{array}$ & $\begin{array}{c}0 \\
0.0 \\
\end{array}$ & $\begin{array}{c}0 \\
0.0 \\
\end{array}$ & $\begin{array}{c}1 \\
0.2 \\
\end{array}$ & $\begin{array}{c}2 \\
0.2 \\
\end{array}$ & $\begin{array}{c}1 \\
0.2 \\
\end{array}$ & $\begin{array}{c}5 \\
0.0 \\
\end{array}$ & $\begin{array}{c}1 \\
0.0 \\
\end{array}$ & $\begin{array}{c}9 \\
0.0 \\
\end{array}$ \\
\hline Indifferent & $\begin{array}{c}\text { species } \\
\%\end{array}$ & $\begin{array}{c}62 \\
99.4\end{array}$ & $\begin{array}{c}61 \\
98.4\end{array}$ & $\begin{array}{c}41 \\
99.6\end{array}$ & $\begin{array}{c}47 \\
99.8\end{array}$ & $\begin{array}{c}50 \\
99.2\end{array}$ & $\begin{array}{c}85 \\
99.8\end{array}$ & $\begin{array}{c}90 \\
99.6\end{array}$ & $\begin{array}{l}144 \\
99.0\end{array}$ \\
\hline Halophilous & $\begin{array}{c}\text { species } \\
\% \\
\end{array}$ & $\begin{array}{c}2 \\
0.0\end{array}$ & $\begin{array}{c}1 \\
0.2\end{array}$ & $\begin{array}{c}0 \\
0.0\end{array}$ & $\begin{array}{c}0 \\
0.0\end{array}$ & $\begin{array}{c}0 \\
0.0\end{array}$ & $\begin{array}{c}1 \\
0.0\end{array}$ & $\begin{array}{c}2 \\
0.0\end{array}$ & $\begin{array}{c}5 \\
0.0\end{array}$ \\
\hline Mesohalobous & $\begin{array}{c}\text { species } \\
\% \\
\end{array}$ & $\begin{array}{c}0 \\
0.0\end{array}$ & $\begin{array}{c}1 \\
0.6\end{array}$ & $\begin{array}{c}1 \\
0.2\end{array}$ & $\begin{array}{c}2 \\
0.0\end{array}$ & $\begin{array}{c}0 \\
0.0\end{array}$ & $\begin{array}{c}1 \\
0.0\end{array}$ & $\begin{array}{c}2 \\
0.2\end{array}$ & $\begin{array}{c}2 \\
0.0\end{array}$ \\
\hline Euhalobous & $\begin{array}{c}\text { species } \\
\% \\
\end{array}$ & $\begin{array}{c}0 \\
0.0\end{array}$ & $\begin{array}{c}0 \\
0.0\end{array}$ & $\begin{array}{c}0 \\
0.0\end{array}$ & $\begin{array}{c}0 \\
0.0\end{array}$ & $\begin{array}{c}0 \\
0.0\end{array}$ & $\begin{array}{c}0 \\
0.0\end{array}$ & $\begin{array}{c}0 \\
0.0\end{array}$ & $\begin{array}{c}1 \\
0.0\end{array}$ \\
\hline$?$ & $\begin{array}{c}\text { species } \\
\%\end{array}$ & $\begin{array}{c}2 \\
0.6\end{array}$ & $\begin{array}{c}5 \\
0.8\end{array}$ & $\begin{array}{c}0 \\
0.0\end{array}$ & $\begin{array}{c}1 \\
0.0 \\
\end{array}$ & $\begin{array}{c}3 \\
0.6\end{array}$ & $\begin{array}{c}7 \\
0.2 \\
\end{array}$ & $\begin{array}{c}2 \\
0.2\end{array}$ & $\begin{array}{l}21 \\
1.0\end{array}$ \\
\hline Number of species & & 66 & 68 & 43 & 52 & 54 & 99 & 97 & 182 \\
\hline
\end{tabular}


Table 3. (Diatom quotient: $\frac{\mathrm{C}}{\mathrm{P}}$ ) (number of valves)

\begin{tabular}{l|r|r|r|r|r|r|r|r}
\hline \multicolumn{1}{c|}{ Sample no. } & 1 & 6 & 11 & 16 & 21 & 26 & 31 & 36 \\
\hline Cyclotella & 68 & 15 & 3 & 2 & 3 & 4 & 2 & 1 \\
Melosira & 184 & 205 & 19 & 9 & 10 & 14 & 3 & 9 \\
Stephanodiscus & 41 & 19 & 8 & 1 & 5 & 5 & 8 & 9 \\
\hline Centrales total & 293 & 239 & 30 & 12 & 18 & 23 & 13 & 19 \\
Pennales total & 207 & 261 & 470 & 488 & 482 & 477 & 487 & 481 \\
Centrales (C) & 1.41 & 0.91 & 0.06 & 0.03 & 0.04 & 0.05 & 0.03 & 0.04 \\
\hline Pennales (P) & & & & & & & & \\
\hline
\end{tabular}

Table 4. (Diatom quotient:, C) (species, counted)

\begin{tabular}{l|r|r|r|r|r|r|r|r}
\hline \multicolumn{1}{c|}{ Sample no. } & 1 & 6 & 11 & 16 & 21 & 26 & 31 & 36 \\
\hline Cyclotella & 6 & 5 & 1 & 1 & 2 & 3 & 2 & 1 \\
Melosira & 4 & 5 & 4 & 3 & 4 & 3 & 2 & 5 \\
Stephanodiscus & 3 & 4 & 4 & 1 & 2 & 3 & 3 & 3 \\
\hline Centrales & 13 & 14 & 9 & 5 & 8 & 9 & 7 & 9 \\
Pennales & 51 & 42 & 28 & 32 & 32 & 31 & 56 & 65 \\
Centrales (C) & 0.25 & 0.33 & 0.32 & 0.16 & 0.25 & 0.29 & 0.13 & 0.14 \\
\hline Pennales (P) & & & & &
\end{tabular}




\section{OBSERVATIONS CONCERNING DIATOMS SHOWN IN PLATES I-V}

Eunotia sudetica O. Müller.?. Hustedt 1930-37, II, p. 219, fig. 764.

Plate I, fig. 1: $30.6 \times 4.7 \mu$. 14-15 striae in $10 \mu$.

This species is very variable, and $\mathrm{I}: 1$ falls outside the variation limits with regard to the breadth of valve $(7-8 \mu)$, and number of striae in $10 \mu(8-11)$ given by HustedT 1930-37, II, p. 219. On the other hand, it complies, on the whole, with the measurements given by A. Cleve-Euler, 1953 a, II, p. 110 (breadth $4-9 \mu$ and $8-11$ striae in $10 \mu$ ).

On account of the distinctly concave ventral margin there must be some hesitation in classing it as E. veneris (Kütz.) O. Müller, which, apart from the form, it resembles quite closely.

Plate I, fig. $2: 33.3 \times 4.5 \mu$. 10-11 striae in $10 \mu$.

This form has concave ventral margin just as $\mathrm{I}: 1$, and, if anything, both may be classed in the form cycle of E. sudetica.

Achnanthes dispar Cleve. HustedT 1930-37, II, p. 394, fig. 842.

Plate 1, fig. 3 a: $26.6 \times 8.0 \mu .17-18$ striae in $10 \mu$. (Raphe valve).

- I, - 3 b: $26.6 \times 8.0 \mu .15$ striae in $10 \mu$. (Rapheless valve).

I:3 has rather coarser striae than given by HUSTEDT 1930-37, II, p. 394

and only a few irregular inserted short striae in the middle of the valve, but resemblance is so great that its identity must be regarded as certain. There is also some similarity with $A$. holsti Cleve, but as the pseudoraphe in $\mathrm{I}: 3 \mathrm{~b}$ is only slightly extended in the middle of the valve, whereas in $A$. holsti there is a very broad extended pseudoraphe, this species must, no doubt, be left out of consideration here.

According to Hustedt 1930-37, II, p. 394 A. dispar is halophilous and found only fairly seldom in the Baltic region both recent and fossil. In this country it has been found in Arreskov Lake (FoGED 1954).

Achnanthes kolbei Hustedt. Hustedt 1930-37, II, p. 397, fig. 846.

Plate I, fig. 4 a, b: $13.4 \times 6.2 \mu .13-15$ striae in $10 \mu$.

A characteristic and easily recognisable species hitherto only found once or twice recent in North Germany (HustedT 1957, p. 245), in the Balkans (Hustedt 1945, p. 909), in Denmark (FoGED, Djursland lakes, not published), and in Rennell Island (Foged 1957, p. 54,4:18, 19).

Achnanthes exigua Grun. Hustedt 1930-37, II, p. 386, fig. 832 a, b.

Plate I, fig. 5 a, b: $12.7 \times 5.2 \mu$. 22-24 striae in $10 \mu$.

Almost identical with A. ScHMIDT's Atlas 413: 9, 10.

Cosmopolitan species, found both recent and fossil. 
Achnanthes lanceolata (Bréb.) Grun. var. rostrata (Østrup) Hustedt. HustedT 1930-37, II, p. 410, figs. $863 \mathrm{i}-\mathrm{m}$.

Plate I, fig. 6 a, b: $18.2 \times 7.5 \mu$. 12 striae in $10 \mu$.

Not quite typical, but identity fairly certain.

Plate I, fig. 7 (rapheless valve): $21.4 \times 8.3 \mu$. 10 striae in $10 \mu$. Only rapheless valves of this type were found in the material. Almost identical with A. SchmidT's Atlas 411:23 from recent water in Finland. Resembles closely A. pseudotanensis A. Cleve-Euler (1953 b, III, p. 25, fig. 524, from South Lapland).

Achnanthes lanceolata var. elliptica Cleve

Plate I, fig. 8 a, b: $9.4 \times 5.2 \mu$. 12 striae in $10 \mu$.

According to Hustedt 1930-37, II, p. 410 the raphe valve is "deutlich zarter gestreift" than the rapheless valve. In I:8 the two valves from the same cell have the same number of striae. This seems also to be the case in A. SchmidT's Atlas 411: 43, 44 (from Finland, recent fresh water), which is identified with this variety.

Achnanthes daui nov. spec. Plate I, fig. 10.

Valvae oblonge ellipticae lateribus paulum convexis, ad apices obtuse rotundatos subito valde attenuatae, 11-12 $\mu$ longae, 5-6 $\mu$ latae; superior rhaphe destituta, pseudorhaphe angusta in medio non dilatata et striis transapicalibus subradiantibus ca. 15 in $10 \mu$, ornata inferior rhaphe subtili instructa, area axiali angusta in medio non dilatata, striis transapicalibus ca. 15 in $10 \mu$.

Valves elongated elliptical, slightly convex, abruptly and strongly tapering and with obtusely rounded apices, $11-12 \mu$ long and 5-6 $\mu$ broad. Rapheless valve with narrow pseudoraphe with no very marked central area. Transapical striae slightly radial, about 15 in $10 \mu$. Raphe valve with threadlike raphe, narrow axial area, no strongly marked central area, about 15 transapical striae in $10 \mu$.

Plate I, fig. $10 \mathrm{a}, \mathrm{b}: 11.4 \times 5.3 \mu$. 15 striae in $10 \mu$.

Illustration slide: Hollerup 2205 (36). Foged collection (Odense).

Type locality: Hollerup, Denmark. Interglacial kieselguhr.

Resembles A. lemmermanni Hustedt (1930-37, II, p. 390, fig. 837), but this has capitate apices, and the number of striae in the two valves is not the same. Named after H. DAU (1790-1831), a Danish geologist; a pioneer in the exploration of the peat bogs.

Cocconeis thumensis A. Mayer. Sensu A. MAYER 1919, 0. 199, 6: 24.

Plate I, fig. 9 a, b: $10.3 \times 6.2 \mu$. 18 striae in $10 \mu$.

According to A. Mayer 1919, p. 199 and Hustedt 1930-37, II, p. 346 there is an equal number of striae in the two valves. Hustedt 1950, p. 347, however, thinks this to be incorrect, and in his opinion the raphe valve should have denser striae than the raphe-less valve. I have expressed the 
same opinion in my earlier papers. As there is no doubt that the two valves in the material here have the same number of striae, I take it that the type discovered here is in agreement with A. MAYER 1919, whereas the forms I have previously mentioned under this name must represent another similar species.

Caloneis bacillum (Grun.) Cleve fo. inflata Hustedt. Hustedt 1949, p. 99, 11: 26-31.

Plate I, fig. $11: 26.8 \times 6.7 \mu .18-20$ striae in $10 \mu$.

Characterized in that the valves are more or less transapically extended in the middle, and in that the terminals are obtusely rounded and slightly cuneate. Doubtless fairly widespread, but both $C$. bacillum and C. silicula (Ehr.) Cleve are so variable, that an infallible determination and description is often difficult or quite impossible.

Caloneis bacillum var. lancettula (Schulz) Hustedt. Hustedt 1930, p. 236, fig. 361.

Plate I, fig. $12: 27.2 \times 4.7 \mu$. 21-22 striae in $10 \mu$.

Rather typical form.

Plate I, fig. 13: $26.0 \times 6.0 \mu$. 20-22 striae in $10 \mu$.

Extreme form of same variety. Closely resembles Foged 1955, p. 47, 3:17 from Pearyland.

Caloneis bacillum var. lancettula forma.

Plate I, fig. $15: 16.7 \times 4.4 \mu .21$ striae in $10 \mu$.

Caloneis silicula (Ehr.) Cleve var. ventricosa Cleve. P. T. Cleve 1894-95, I, p.

52. A. Cleve-Euler 1955, IV, p. 99, fig. 1144 b.

Plate I, fig. $14: 35.0 \times 7.5 \mu$. About 20 striae in $10 \mu$.

Typical form.

Caloneis bacillum forma (?).

Plate I, fig. $16: 12.0 \times 4.7 \mu$. 24 striae in $10 \mu$.

Characterized in the unusually broad central area, but otherwise in fairly close agreement with the species. Could perhaps be classed with C. bacillum var. fontinalis Grun.. (HustedT 1937/39, p. 282, 15: 17-19).

Østrupia zachariasi (Reichelt) Hustedt.

Syn.: Caloneis zachariasi Reichelt. Hustedt 1930, p. 234, fig. 353. Diploneis mauleri Brun var. barussica Cleve.

Plate II, fig. 1: $22.7 \times 8.0 \mu$. 11-12 striae in $10 \mu$.

II:1 corresponds fairly exactly with ØSTRUP 1899, 2:9, the valve breadth of which, according to the figure, is also $8 \mu$, and not as given by Østrup $4 \mu$. ØSTRUP found isolated specimens of this species at Hollerup and Trelde. It has also been found, though rather rarely, recent in North German lakes (Hustedt 1950, p. 404). It is known only fossil from Denmark (Østrup 1899) and from Sweden and Finland (A. Cleve-Euler 1955, IV, p. 91). 
Stauroneis nathorstii nov. spec. Plate II, fig. 2.

Valvae lineari-ellipticae lateribus paulum convexis, ad apices late productos attenuatae, $40 \mu$ longae, $8 \mu$ latae. Septa brevia, valida ad apices sita. Rhaphe recta. Area axialis anguste linearis, prope medium nonnihil dilatata; centralis in stauron angustum ad margines dilatata. Striae transapicales angulum paene rectum cum rhaphe formantes, 20-22 in $10 \mu$, satis manifesto punctatae.

Valves linear-elliptical with slightly convex sides and somewhat tapering, broadly drawn-out, apices, $40 \mu$ long, $8 \mu$ broad. Short strong septa at the valve poles. Raphe straight. Axial area narrow, linear, increasing somewhat in breadth towards the middle of the valve. Central area is a narrow cross band reaching to the margin of the valve. Transapical striae almost at right angles to the raphe, $20-22$ in $10 \mu$, quite distinctly punctate.

Plate II, fig. 2: $40.0 \times 8.0 \mu$. 20-22 striae in $10 \mu$.

Illustration slide: Hollerup 2205 (28). FoGED collection (Odense).

Type locality: Hollerup, Denmark. Fresh water kieselguhr, interglacial.

II: 2 differs from the closely associated $S$. lauenburgiana Hustedt (syn.: $S$. alabamae Heiden var. minuta Heiden), Hustedt 1959 b, p. 809, in being regularly punctate, whereas S. lauenburgiana has "Punkte unregelmässig wellige Längsreihen bildend, die im mittleren Teil aufgelochert sind und entfernter stehen als in der Randzone" (HustedT 1959 b, p. 809). S. lauenburgiana has been found in kieselguhr in North Germany and in Eifel. Named after the Swedish geologist A. G. NATHORST (1850-1921), who was the first to identify remains of arctic plants in Danish peat bogs.

Neidium sp.

Plate II, fig. $3: 41.3 \times 10.3 \mu$. 18 striae in $10 \mu$.

Possibly a $N$. species (without terminal septa).

Found only with a defective valve.

Diploneis oculata (Bréb.) Cleve. Hustedt 1930, p. 250, fig. 392.

Plate II, fig. 6: $18.7 \times 5.6 \mu$. 24 striae in $10 \mu$.

Navicula menisculus Schum. Hustedt 1930, p. 301, fig. 517.

Plate II, fig. $4: 46.7 \times 12.7 \mu$. 8 striae in $10 \mu$.

Difficult to distinguish from N. meniscus Schum.. (Hustedt 1950, p. 447, 39: 19, 20) which is usually given as a brackish water species, probably identical with $N$. peregrina (Ehr.) Kütz. var. meniscus Cleve (1894-95, I, p. 18).

Navicula hartzii nov. spec. Plate II, fig. 5.

Valvae late ellipticae, apicibus satis acute productis, $48 \mu$ longae, ca. $12 \mu$ latae. Area axialis angusta, medio in aream centralem irregulariter rotundatam dilatata. Rhaphe recta, fissuris terminalibus ad idem latus deflexis. Striae transapicales 10 in $10 \mu$, omnes valde radiantes, crassius punctatae, brevioribus nonnullis in media parte intermissis. 
Valves broadly elliptical with rather pointed drawn-out apices, $48 \mu$ long, about $12 \mu$ broad. Axial area narrow extending in the middle to a somewhat irregular rounded central area. Raphe straight with terminal fissures bent to the same side. 10 transapical striae in $10 \mu$, all strongly radial and quite coarsely punctate. In the middle of the valve isolated, shorter, inserted striae.

Plate II, fig. 5: $40.0 \times 11.8 \mu$. 10 striae in $10 \mu$.

Illustration slide: Hollerup 2205 (3). FoGED collection (Odense).

Type locality: Hollerup, Denmark. Interglacial fresh water kieselguhr.

The species resembles $N$. helmandensis Foged (1959, p. 60, 6:13), which does not, however, have the inserted shorter striae in the middle of the valve. Named after N. HarTz (1867-1937), Danish botanist, who identified interglacial peat bog deposits in Jutland.

Navicula mentzii nov. spec. Plate II, fig. 7.

Valvae late ellipticae, apicibus rotundatis non productis, 38-40 $\mu$ longae, 13-14 $\mu$ latae. Area axialis angusta, medio in aream centralem parvam rotundatam dilatata. Rhaphe tenuis, fissuris terminalibus ad idem latus deflexis. Striae transapicales $8-9$ in $10 \mu$, radiantes, ad apices versus angulum rectum cum rhaphe formantes, manifesto lineolatae.

Valves broadly elliptical with rounded not drawn-out apices, 38-40 $\mu$ long, $13-14 \mu$ broad. Axial area narrow, in the middle of the valve extending to a small rounded central area. Raphe linear with terminal fissures bent to the same side. 8-9 transapical striae in $10 \mu$, radial, towards the apices at right angles to the raphe, distinctly lineolate.

Plate II, fig. 7: $38.6 \times 13.3 \mu$. $8-9$ striae in $10 \mu$. Illustration slide: Hollerup 2205 (6). FoGED collection (Odense).

Type locality: Hollerup, Denmark. Interglacial fresh water kieselguhr.

Resembles N.meniscus Schum. (Hustedt 1950, p. 447, 39: 19, 20), but differs from it in having no shorter inserted striae in the middle of the valve. Named after A. Mentz (1867-1944), Danish botanist, who has made valuable contribution to the exploration of Danish peat bogs.

Navicula placentula Ehr. fo. rostrata A. Mayer. Hustedt 1930, p. 304, fig. 533. Plate II, fig. 8: $40.0 \times 16.0 \mu .9$ striae in $10 \mu$.

Navicula placentula fo. jenisseyensis (Grun.) Meister. Hustedt 1930, p. 303, fig. 536.

Plate II, fig. 9: $41.3 \times 15.3 \mu .9$ striae in $10 \mu$.

Rather broader valves than usual, but otherwise in agreement with this form.

Plate III, fig. $1: 46.0 \times 12.0 \mu .10$ striae in $10 \mu$.

Central area rather larger than usual, but otherwise typical.

No inserted shorter striae in the middle of the valve in II: 9. 
Navicula meniscoides Hustedt. Hustedt 1955, p. 29, 9: 4, 5.

Plate II, fig. $10: 26.0 \times 9.3 \mu$. 10 striae in $10 \mu$.

Rather dubious, but resemblance is great. Thus in II:10, "Central area is scarcely separated", and striae are "slightly radiate throughout", and again, it has "more or less acute sub-rostrate ends", properties characteristic of N. meniscoides. Resembles N. peregrina var. meniscus, but differs from this in that there is no central area and the course of the striae is also otherwise. $N$. meniscoides has, previously, only been identified on the coast of North Carolina (HustedT 1955).

Navicula rotunda Hustedt. Hustedt 1945, p. 916, 41: 29.

Plate II, fig. $11: 12.0 \times 5.3 \mu .18-20$ striae in $10 \mu$.

II:10 is somewhat more elliptically elongated than usual in this species.

Navicula modica Hustedt. Hustedt 1945, p. 916, 41: 21-23.

Plate II, fig. $12: 10.6 \times 4.6 \mu$. 16-17 striae in $10 \mu$.

Found recent both in the Balkans and in North German lakes.

Navicula clementis Grun. A. Schmidts Atlas 398:12. Brockmann 1950, p. 18, 2: 59.

Plate III, fig. $2: 31.5 \times 11.3 \mu$. 11-12 striae in $10 \mu$.

Occurs in both fresh water and brackish water (Hustedt 1959 a, p. 289).

I have found it recent in my own material from Denmark, Sweden, Norway, Svalbard, Iceland and Ireland, and fossil in Jutland (Vejlby) and in Zealand (Aamosen).

Navicula exigua (Greg.) O. Müller. var. signata Hustedt. Hustedt 1944, p. 287, fig. 14.

Plate III, fig. $6: 30.0 \times 10.8 \mu .9$ striae in $10 \mu$.

Typical specimen of this form, not often found, and first shown to exist by Husted 1944 in North German lakes.

Plate III, fig. $3: 31.4 \times 11.3 \mu$. 9 striae in $10 \mu$.

The striae in the middle of the valve not quite in agreement with the usual type, but otherwise great resemblance.

Navicula hungarica Grun. Hustedt 1930, p. 298, fig. 506. A. Cleve-Euler 1953 b, III, p. 137, fig. 782 a.

Plate III, fig. $4: 30.7 \times 8.2 \mu$. About 9 striae in $10 \mu$.

III:4 has central area developed as a distinct transverse band extending to the sides of the valve, and the striae at apices distinctly convergent. This agrees almost entirely with the form shown by A. CLEVE-EULER in illustration, 1953 b, III, fig. 782 a.

A species with numerous forms which on the border-line could be mistaken for forms of $N$. costulata Grun. In the typical valves of the latter all the striae are strictly radial.

Plate III, fig. 5: $28.0 \times 7.3 \mu$. $8-9$ striae in $10 \mu$.

Complies fairly exactly with III:4. 
Navicula sp. Plate III, fig. 7.

$32.0 \times 12.6 \mu$. About 9 striae in $10 \mu$.

Defect valve with the one end missing so that the nature of the branches of the raphe at the poles cannot be ascertained. Appears to resemble closely N. constans Hustedt var. symmetrica Hustedt (1957, p. 289, fig. 41). This variety differs from the species in having no isolated stigma in the central area. N. constans (HustedT 1944, 8:13) is found in interglacial kieselguhr at Lüneburg (HustedT 1944, p. 284) and recent in Norway (Foged 1960 b, $1: 3)$.

Navicula hungarica Grun. var. lüneburgensis Grun. Hustedt 1930, p. 298, fig. 509.

Plate III, fig. $8: 34.7 \times 7.4 \mu$. 9 striae in $10 \mu$.

Not a very common variety. Found recent by Hustedt $(1957$, p. 293) in the Baltic region, and fossil in kieselguhr at Lüneburg (HustedT 1957, p. 293), in kieselguhr of Funen (FOGED 1954 a) and in kieselguhr of Jutland (Foged 1960 a).

Navicula costulata Grun. Hustedt 1930, p. 298, fig. 505.

Plate III, fig. 9: $25.3 \times 6.0 \mu$. 8 -9 striae in $10 \mu$.

Typical specimen of this fairly widespread species.

Navicula graciloides A. Mayer. HustedT 1930, p. 299, fig. 515.

Plate III, fig. $10: 32.0 \times 6.7 \mu$. 11-12 striae in $10 \mu$.

Long, narrow form of the species.

Plate III, fig. $11: 19.3 \times 7.0 \mu .12$ striae in $10 \mu$.

Short, but otherwise typical form of the species.

Navicula diversistriata Hustedt. ?. Hustedt 1955 a, p. 28, 9: 6-9.

Plate III, fig. $12: 17.4 \times 6.7 \mu .12$ striae in $10 \mu$.

The two valves are quite different with regard to the direction of the striae. In the one, the striae are at right angles to the raphe, whereas in the other, the striae are strictly radial in the middle of the valve. According to Husted 1955 a, p. 28 there is also a difference in the number of striae in the two valves (16 and 12-14 in $10 \mu)$. In III:12 there is no difference in this respect. Both valves have 12 striae in $10 \mu$. HustedT (1955 a) has found the species fairly widespread in marine littoral in North Carolina.

A similar difference between the structure of the two valves has been ascertained in N. antediluviana Hustedt (1954 c, p. 132, figs. 2, 3) which has been found fossil (tertiary) in Rumania, and in N. sp. (Foged 1959, p. 63, 4: $12 \mathrm{a}, \mathrm{b})$ from fresh water (recent) in Afghanistan.

Navicula cincta (Ehr.) Kütz. var. heufleri Grun. Hustedt 1930, p. 298, fig. 511.

Plate III, fig. 13: $18.0 \times 4.2 \mu$. About 10 striae in $10 \mu$.

Small form of this fairly widespread variety. 
Navicula jessenii nov. spec. Plate III, fig. 14.

Valvae ellipticae, apicibus acutioribus, 25-26 $\mu$ longae, 6-7 $\mu$ latae. Area axialis angusta, medio in aream centralem parvam dilatata, striis binis medianis paulum abbreviatis. Rhaphe recta, fissuris terminalibus ad idem latus deflexis. Striae transapicales 9 in $10 \mu$, valde radiantes, punctatae (lineolatae). Valves elliptical with sharply rounded apices, 25-26 $\mu$ long, 6-7 $\mu$ broad. Axial area narrow, extending in the middle of the valve to a small central area, the two opposite striae in the middle being a little shortened. Raphe straight, terminal fissures bent to the same side. 9 strongly radial transapical striae, punctate (lineolate), in $10 \mu$.

Plate III, fig. 14: $25.3 \times 6.7 \mu .9$ striae in $10 \mu$.

Illustration slide: Hollerup 2205 (9). FoGED collection (Odense).

Type locality: Hollerup, Denmark. Interglacial fresh water kieselguhr.

Resembles $N$. pseudogracilis Hustedt (1927, p. 224, 8: 4), but this is larger (35-50 $\mu$ long) and striae "um den Zentralknoten weitläufiger gestellt".

Dedicated to Knud Jessen, Professor, Ph. D., Danish botanist; a pioneer in the modern exploration of the peat bogs.

Navicula pupula Kütz. var. hollerupensis nov. var. Plate IV, fig. 1.

A var. pupula differt valvis medio valde dilatatis, ad apices versus valde attenuatis, striis in media parte multo magis distantibus (14-15 in $10 \mu$ ) quam ad apices (ca. 24 in $10 \mu$ ).

Differs from the species in having valves strongly extended in the middle and sharply tapering towards the apices. Very great difference in density of striae in middle of valve $(14-15$ in $10 \mu)$ and at the apices (about 24 in $10 \mu$ ). Plate IV, fig. $1: 37.4 \times 7.0 \mu$. In the middle of the valve $14-15$ striae, at the apices $24-25$ in $10 \mu$.

Illustration slide: Hollerup 2205 (34). FoGED collection (Odense).

Type locality: Hollerup, Denmark. Interglacial fresh water kieselguhr.

Navicula laterostrata Hustedt. Hustedt 1930, p. 301, fig. 521.

Plate IV, fig. 2: $32.3 \times 10.0 \mu$. 14-15 striae in $10 \mu$.

According to Husted 1950, p. 401 this species is a characteristic guide form in the case of post glacial deposits in North Germany. It is fairly widespread recent, but rather rare. Also found in kieselguhr in Funen.

Navicula bacillum Ehr. HustedT 1930, p. 280, fig. 465 a.

Plate IV, fig. $3: 27.3 \times 9.4 \mu$. 18 striae in $10 \mu$ in the middle of the valve, denser towards the poles.

Density of striae rather greater than normal in the species (about 12-14 in $10 \mu$ in middle of the valve), but density of striae not so dense as in the species $N$. bacilloides Hustedt which it resembles.

Plate IV, fig. $4: 17.2 \times 8.2 \mu .18$ striae in $10 \mu$ in middle of valve. Almost identical with Hustedt 1930, fig. 465 c. 
Navicula rotunda Hustedt. Hustedt 1945, p. 916, 41: 29. 1950, p. 353, 38: 35-39. 1954 b, p. 472, figs. 41-50.

Plate IV, fig. 5: $13.4 \times 8.7 \mu$. About 16 striae in $10 \mu$.

Very widespread recent, though not common. Also found in kieselguhr at Randsfjord (FogED 1960 a).

Navicula interglacialis Hustedt. Hustedt 1944, p. 286, fig. 27. 1954, p. 453, fig. 16.

Plate IV, fig. $6: 18.0 \times 8.7 \mu$. About 15 striae in $10 \mu$.

A very characteristic species which also seems to be very widespread recent. Its occurrence has been ascertained in West Greenland (FogED 1958), in Finland and Sweden (Hustedt 1954 a), in North Norway (Foged 1960 b), in Iceland (FogED, not published), and at Spitsbergen (FoGED, in press). Also found in kieselguhr in Funen (Foged 1954 b) and at Randsfjord (FoGED 1960 a).

Navicula jentzschii Grun. Hustedt 1930, p. 310, fig. 556.

Plate IV, fig. $7: 18.0 \times 9.8 \mu .15-16$ striae in $10 \mu$.

Stauroneis thermicola (Boye Petersen) Lund. J. W. G. Lund 1946, p. 61, figs. 3 $\mathrm{K}-\mathrm{AA}$.

(Syn.: Navicula contempta Krasske. Hustedt 1930, p. 307).

Plate IV, fig. $8: 16.0 \times 5.0 \mu$. About 20 striae in $10 \mu$

Navicula hollerupensis nov. spec. Plate IV, fig. 9.

Valvae lineari-ellipticae, apicibus late rostratis, obtuse rotundatis, 16-17 $\mu$ longae, 5-6 $\mu$ latae. Area axialis angustissima; centralis parva, rotundata. Striae transapicales radiantes, ad apices convergentes, satis crasse punctatae, $18-20$ in $10 \mu$, ad apices paulum densius confertae.

Valves linear-elliptical with broadly rostrate, obtusely rounded poles, 16-17 $\mu$ long, 5-6 $\mu$ broad. Axial area very narrow. Central area small, rounded. Transapical striae radial, converging at the poles, rather coarsely punctate, $18-20$ in $10 \mu$, somewhat denser at the poles.

Plate IV, fig. 9: $16.7 \times 5.3 \mu$. 18-20 striae in $10 \mu$.

Illustration slide: Hollerup 2205 (31). FoGED collection (Odense).

Type locality: Hollerup, Denmark. Interglacial fresh water kieselguhr.

Differs from $N$. grimmei Krasske and $N$. thienemanni Hustedt in having converging striae at the apices.

Navicula hustedti Krasske var. obtusa Hustedt. Hustedt 1950, 37: 30.

A. SchmidT's Atlas 400: 57, 58.

Plate IV, fig. 10: $15.3 \times 4.7 \mu$. 20-21 striae in $10 \mu$.

Agrees fairly accurately in all respects with the illustrations given above, which show valves with convergent apical striae just as in IV: 10.

Navicula iversenii nov. spec. Plate IV, fig. 11.

Valvae ellipticae, apicibus capitatis, anguste productis, $20 \mu$ longae, $6-7 \mu$ 
latae. Area axialis angustissima, centralis nulla. Striae transapicales radiantes, satis crasse punctatae, 15-16 in $10 \mu$, ad apices densius confertae.

Valves elliptical with narrow drawn-out capitate poles, $20 \mu$ long, 6-7 $\mu$ broad. Axial area very narrow. No central area. Transapical striae radial, rather coarsely punctate, $15-16$ in $10 \mu$, somewhat denser towards apices.

Plate IV, fig. $11: 20.0 \times 6.5 \mu$. $15-16$ striae in $10 \mu$.

Illustration slide: Hollerup 2205 (36). FoGED collection (Odense).

Type locality: Hollerup, Denmark. Interglacial fresh water kieselguhr.

Dedicated to Johs. Iversen, Ph. D., Danish geologist and botanist.

Navicula acceptata Hustedt.?. Hustedt 1954 a, p. 453, figs. 18-22. 1955, p. 398, 38: 66, 67.

Plate IV, fig. $12: 12.0 \times 5.3 \mu$. 15-16 striae in $10 \mu$.

This species which is fairly common in interglacial deposits at Oberohe has striae almost at right angles to the raphe ("subradiantes vel ad liniam mediam perpendicularis").

IV:12 has quite distinct radial striae. Determination therefore somewhat doubtful.

Navicula sp.

Plate IV, fig. 13: $17.4 \times 8.0 \mu .18$ striae in $10 \mu$.

Navicula paludosa Hustedt. Hustedt 1957, p. 286.

Plate IV, fig. $14: 22.0 \times 5.8 \mu$. $14-15$ striae in $10 \mu$.

(Syn.: N. lagerstedti Cleve var. palustris Hustedt).

Navicula schönfeldii Hustedt. HustedT 1930, p. 301, fig. 520.

Plate IV, fig. 15: $16.0 \times 5.8 \mu$. About 9 striae in $10 \mu$.

Navicula vitabunda Hustedt. Hustedt 1954 b, p. 473, fig. 54.

Plate IV, fig. $16: 17.5 \times 6.0 \mu$. 20-24 striae in $10 \mu$.

Navicula hungarica Grun. var. lüneburgensis Grun. HuSTEDT 1930, p. 298, fig. 509. Schulz 1926, p. 207, fig. 86 c.

Plate IV, fig. 17: $18.6 \times 4.6 \mu$. 10 striae in $10 \mu$.

A somewhat extreme form of this variety, which according to the illustrations in the given papers, all have radial striae, whereas the species and other varieties have convergent apical striae.

ØSTRuP 1899, p. 44 mentions to have found this species at Hollerup.

Navicula milthersii nov. spec. Plate IV, fig. 18.

Valvae ellipticae, apicibus rotundatis, satis anguste productis, $14-15 \mu$ longae, 6-7 $\mu$ latae. Area axialis angusta, medio in aream centralem latiorem quam longiorem circiter dimidiam valvae latitudinem attingentem dilatata. Striae transapicales radiantes, medio ca. 20 in $10 \mu$, ad apices versus densius confertae. Valves elliptical with rather narrow drawn-out rounded poles, 14-15 $\mu$ long, 6-7 $\mu$ broad. Narrow axial area broadening in the middle of the valve to a transversely extended central area covering about half the breadth of the 
valve. Transapical striae radial, in the middle of the valve about 20 in $10 \mu$. Denser at the poles.

Plate IV, fig. $18: 14.7 \times 6.2 \mu$. 21 striae in $10 \mu$.

Illustration slide: Hollerup 2205 (36). FoGED collection (Odense).

Type locality: Hollerup, Denmark. Interglacial fresh water kieselguhr.

Named after V. Milthers (1865-1962), Ph. D. h. c., Danish geologist, who has yielded important contribution to the interpretation of the origin and development of the Danish landscape.

Navicula rotunda Hustedt. HustedT 1954 b, p. 472, figs. 41-50.

Plate IV, fig. 19: $7.9 \times 4.7 \mu$. About 18 striae in $10 \mu$.

Very variable species. (See IV:5.)

Navicula excelsa Krasske. Hustedt 1930, p. 306, fig. 545.

Plate IV, fig. $20: 12.7 \times 6.6 \mu$. 18-19 striae in $10 \mu$.

Navicula vaupellii nov. spec. Plate IV, fig. 21.

Valvae ellipticae, $12-13 \mu$ longae, $4-5 \mu$ latae. Area axialis angusta; centralis nulla praeter axialem prolongatam. Rhaphe recta. Striae transapicales subradiantes, punctatae, ca. 21-22 in $10 \mu$.

Valves elliptical, $12-13 \mu$ long, $4-5 \mu$ broad. Narrow axial area, no central area. Raphe straight. Transapical striae slightly radial, punctate, about 21-22 in $10 \mu$.

Plate IV, fig. $21: 12.7 \times 4.7 \mu$. 21-22 striae in $10 \mu$.

Illustration slide: Hollerup 2205 (36). FoGED collection (Odense).

Type locality: Hollerup, Denmark. Interglacial fresh water kieselguhr.

Named after C. VAupell (1821-1862), Danish botanist; the earliest real Danish phytobiologist and ecologist, who also has made valuable contribution to the interpretation of the geological development of the peat bogs.

Navicula warmingii nov. spec. Plate IV, fig. 22.

Valvae lineares, apicibus late rotundatis, 14-15 $\mu$ longae, $4 \mu$ latae. Area axialis angusta, medio paulum dilatata. Rhaphe recta. Striae transapicales paululum radiantes, angulum paene rectum cum rhaphe formantes, punctatae, ca. 22 in $10 \mu$.

Valves linear with broadly rounded poles, 14-15 $\mu$ long, $4 \mu$ broad. Axial area narrow, slightly broader in the middle of the valve. Raphe straight. Transapical striae very slightly radial, almost at right angles to the raphe, punctate, about 22 in $10 \mu$.

Plate IV, fig. 22: $14.7 \times 4.0 \mu$. About 22 striae in $10 \mu$.

Illustration slide: Hollerup 2205 (34). Foged collection (Odense).

Type locality: Hollerup, Denmark. Interglacial fresh water kieselguhr.

Named after E. WARMING (1841-1924), Danish botanist and plant ecologist.

Navicula schadei Krasske. Sensu A. SchmidT's Atlas 398: 32-35.

Plate IV, fig. $23: 13.3 \times 5.4 \mu$. 22-24 striae in $10 \mu$. 
IV: 23 has all the striae radial, resembling AS 398: 32-35, whereas KrassKe 1929 gives that the striae are "strahlend, an den Enden konvergierend". In the text to AS 398: 32-35 Hustedt says: "Die Abbildungen der von KrassKe beschriebenen Arten sind nach der Originalpräparaten bzw. nach Originalmaterialen gegeben". From experience it is often difficult, in the case of the small species, to determine whether the apical striae are convergent or slightly radial, as the impression obtained can depend on higher or lower adjustment of the objective, especially when the valves are very much crumpled.

Navicula similis Krasske. Krasske 1929, p. 354, fig. 15. A. Schmidt's Atlas 370: 17, 18. 401: 8, 9. Hustedt 1930, p. 303, fig. 528.

Plate IV, fig. $24: 18.7 \times 7.4 \mu$. $12-13$ striae in $10 \mu$.

In spite of rather coarser striae than usual (about 16 in $10 \mu$ ), IV:24 must undoubtedly be classed with this species.

Pinnularia lenticula A. Cleve-Euler var. brevistriata A. Cleve-Euler. A. CleveEULER 1955, IV, p. 56, fig. 1074 d.

Plate V, fig. 1: $54.0 \times 10.8 \mu$. 10 striae in $10 \mu$.

Cleve-Euler's form is given as having 13-14 striae in $10 \mu$, but otherwise there is close agreement. A form belonging to the group Divergentes and closely associated with the form cycle of $P$. microstauron var. lanceolata Østrup (1910, p. 98, 3:63) in which, however, the striae are longer than in $\mathrm{V}: 1$.

A. Cleve-Euler's form is found only very rarely fossil in Sweden.

Pinnularia microstauron (Ehr.) Cleve var. ambigua Meister. OKuno 1952, 26 : 18, 19. Hustedt 1930, p. 320.

Plate V, fig. 2: $49.3 \times 6.8 \mu$. 9-10 striae in $10 \mu$.

Pinnularia karelica Cleve. Hustedt 1930, p. 322, fig. 586.

Plate V, fig. 3: $28.7 \times 9.5 \mu$. 11-12 striae in $10 \mu$.

Smaller form of this, otherwise, characteristic species.

Pinnularia intermedia Lagerst. J. W. G. Lund 1946, p. 92, figs. 12 A, B.

J. Boye Petersen 1928, p. 405.

Plate V, fig. 4: $30.0 \times 5.6 \mu$. About 9 striae in $10 \mu$.

Pinnularia lagerstedti (Cleve) Hustedt. Hustedt 1957, p. 311.

Syn.: P. parva (Greg.) Cleve var. minuta Østrup (1918, p. 36, 4: 55).

Plate V, fig. 5: $20.7 \times 6.1 \mu$. 9 striae in $10 \mu$.

Gomphonema abbreviatum Agardh ?. Kütz. forma. Hustedt 1930, p. 379.

Plate V, fig. 6: $30.0 \times 6.0 \mu$. 18 striae in $10 \mu$.

It is quite closely associated to fo. inflata Hustedt (1953, p. 630, fig. 21) from South Germany (fresh water, recent). The species is fairly rare. In Denmark identified in lakes of Funen (FoGED 1954).

Gomphonema intricatum Kütz. var. pumila Grun. HusTEDT 1930, p. 375, fig. 699. 
Plate V, fig. 7: $20.6 \times 4.6 \mu$. 12 striae in $10 \mu$.

Not typical.

Gomphonema sp.

Plate V, fig. 8: $37.5 \times 8.0 \mu$. About 15 striae in $10 \mu$.

Almost identical with A. SchmidT's Atlas 240:4,5, which represents a transitional form between G. acuminatum Ehr. and G. augur Ehr. Many G. species are extremely variable, and cases of doubt in identification of them are frequent.

Gomphonema gracile Ehr. HustedT 1930, p. 376, fig. 702.

Plate V, fig. $12: 39.5 \times 5.5 \mu$. 9-10 striae in $10 \mu$.

Axial area is somewhat broader than usual in this species.

Gomphocymbella ancyli (Cleve) Hustedt. Hustedt 1930, p. 366, fig. 681.

Plate V, fig. 10: $28.6 \times 8.0 \mu$. 8-9 striae in $10 \mu$.

Found only in sample No. 11 here at Hollerup. The isolated stigma usually present in the central area seems to be missing here, but as this is sometimes the case with regard to recent valves which can definitely be classed with this species (FOGED $1960 \mathrm{c}$ ), the determination can be made with certainty in so far as the other characteristics are present.

Amphora ovalis Kütz. var. libyca (Ehr.) Cleve. Hustedt 1930, p. 342.

Plate V, fig. $11: 34.0 \times 5.6 \mu$. 12-13 striae in $10 \mu$.

Differs somewhat from the common type.

Amphora triundulata Ross. Ross 1947, p. 222, 11: 13.

Plate V, fig. 13: $20.0 \times 4.0 \mu$. 18-20 striae in $10 \mu$.

A species which seems to be very widespread (FoGED 1960 a, p. 202).

Syn.: A. normanni Rabh. var. undulata Krasske and A. duseni Brun.

Cymbella thumensis (A. Mayer) Hustedt 1945, p. 938, 42: 60-62.

Syn.: C. parvula Krasske (1933, p. 92, fig. 3). Fossil.

Plate V, fig. $15: 11.3 \times 4.7 \mu .18-19$ striae in $10 \mu$.

A small, very characteristic species previously found recent in the Balkans and in North Germany (Hustedt 1945, 1950), in Sweden (A. Cleve-Euler $1953 \mathrm{~b}, \mathrm{III}$ ), and Iceland (FoGED, not published), and fossil in Germany (Krasske 1933) and in Sweden (A. Cleve-Euler 1953 b, III).

Cymbellonitzschia diluviana Hustedt. Hustedt 1950, p. 395.

Plate V, fig. $14: 16.0 \times 3.6 \mu$. 7-8 carinate dots and about 24 striae in $10 \mu$. Less frequent here than in kieselguhr at Randsfjord. Fairly frequent recent (FoGED $1960 \mathrm{c}$ ).

Nitzschia hollerupensis nov. spec. Plate V, fig. 9.

Valvae lineares, ad apices subcapitatos paulum attenuatae, 40-65 $\mu$ longae, 4-5 $\mu$ latae. Puncta carinalia 8-9 in $10 \mu$, intervallis aequalibus disjuncta. Striae transapicales 18 in $10 \mu$, punctatae, punctis 20-22 in $10 \mu$.

Valves linear, somewhat tapering towards the poles which are slightly ca- 
pitate. Length $40-65 \mu$, breadth $4-5 \mu$. Puncta carinalia $8-9$ in $10 \mu$, intervals equal. 18 transapical striae in $10 \mu$. Striae punctate, 20-22 puncta in $10 \mu$.

Plate V, fig. 9: $62.0 \times 4.2 \mu$. 8-9 carinate dots and 18 striae in $10 \mu$. Illustration slide: Hollerup 2205 (11). FogED collection (Odense).

Type locality: Hollerup, Denmark. Interglacial fresh water kieselguhr. A very similar species is common in some lakes in Djursland, Jutland (FoGED, not published). 


\section{TABLE OF THE DIATOMS FOUND IN DANISH INTERGLACIAL KIESELGUHR}

In table 5, p. 28, is given a list, in alphabetical order, of all the diatoms found in Danish interglacial kieselguhr deposits (fresh water), up to the present time. In the first vertical column are shown the species identified by ØSTRUP 1899 in the kieselguhr deposits of Jutland. Following this there is a column showing the species found in Funen by Møller 1943 and Foged 1954. In column 3 the species identified in the South Jutland kieselguhr deposits at Vejlby (Foged 1960) are shown. The following columns give the result of the analysis of the samples from the Hollerup section. In the same way as in FoGED 1960, this section was divided into groups (Nos. 1-5, 6-10, 11-15, 16-18, 19-22, 23-27, 28-32, 33-36), and a final stage - the uppermost part of the section - comprising 2 samples (Nos. 37-38). The figures give the number of samples in which the particular species is found at each stage, and in the last column the number of samples in which the species is found in the Hollerup section. The figures in the Funen and Vejlby columns show, correspondingly, the frequency of the species in the deposits investigated from these localities. Nearest the edge (last vertical column) is shown the diatoms found on investigation of samples from a kieselguhr deposit at Vellev, about $2 \mathrm{~km}$ west of Hollerup. These samples were also taken 11.8.1949. The kieselguhr deposit at Vellev is no longer quarried. Presumably this deposit was formed at the same time as the Hollerup deposits.

From the last horizontal row of figures, can be seen the number of diatoms occurring in the samples of the vertical column above each figure. The total number of diatom forms identified in Danish interglacial kieselguhr deposits is 467 . Of these 18 species only have been identified by ØSTRUP 1899, 3 have been found by ØSTRUP 1899 and MøLler 1944, and 6 have only been observed by Møller 1944. The other species observed by ØSTRup 1899 and Møller 1944 have all been found again in the material I have investigated, in which the total number of forms identified was 440 . 
Table 5

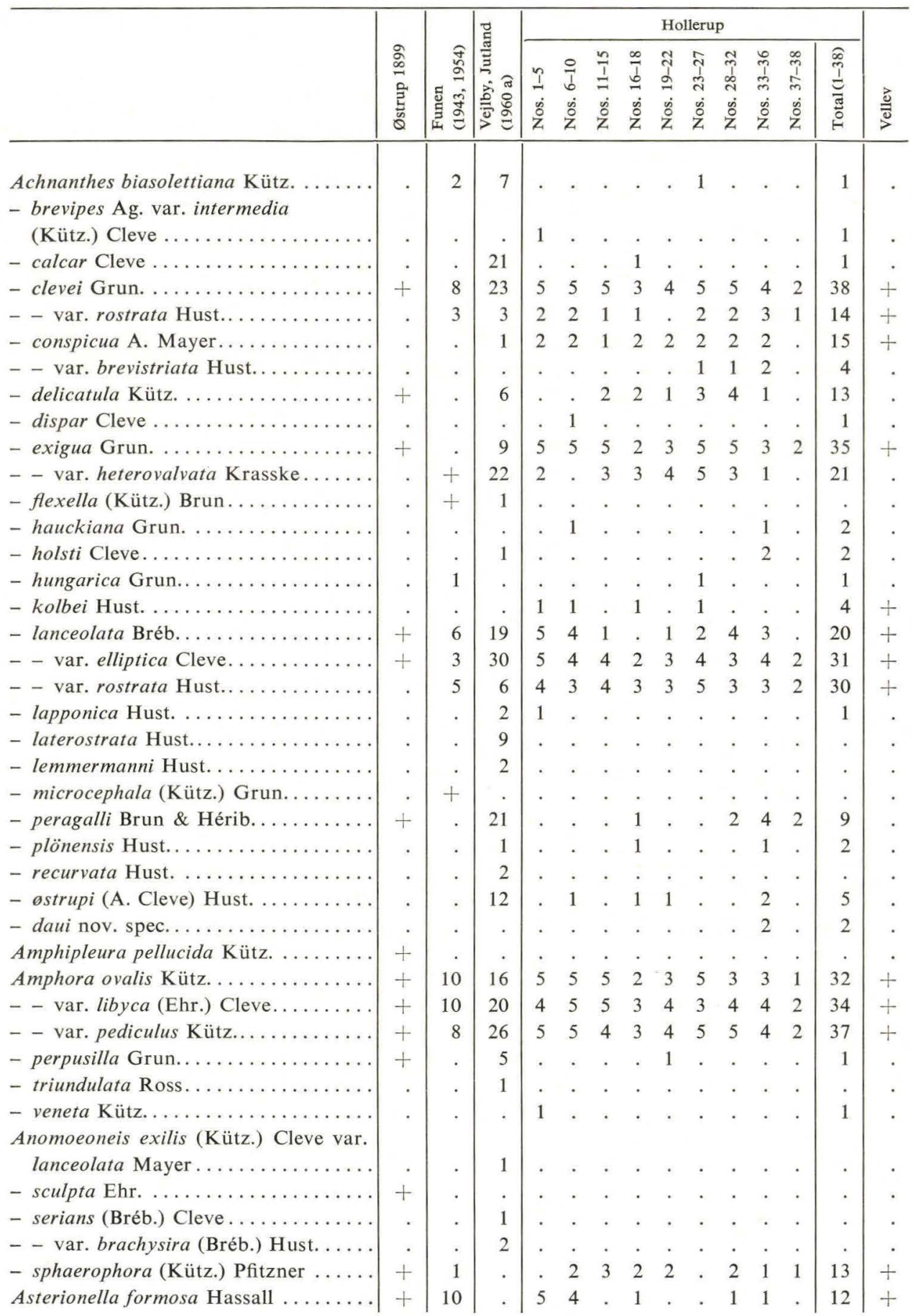




\begin{tabular}{|c|c|c|c|c|c|c|c|c|c|c|c|c|c|c|}
\hline & & & & & & & & & the & & & & & \\
\hline & 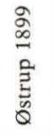 & 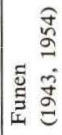 & 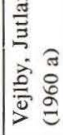 & $\begin{array}{l}n \\
1 \\
\text { co } \\
\text { ż }\end{array}$ & 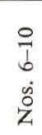 & $\begin{array}{l}\stackrel{n}{I} \\
\stackrel{1}{\prime} \\
\dot{0} \\
\ddot{z}\end{array}$ & $\begin{array}{l}\stackrel{\infty}{\vec{b}} \\
\stackrel{0}{\dot{0}} \\
\dot{0}\end{array}$ & $\begin{array}{l}\frac{1}{2} \\
\dot{0} \\
\stackrel{0}{z}\end{array}$ & $\begin{array}{l}\tilde{N} \\
\tilde{n} \\
\tilde{N} \\
\dot{0} \\
\dot{z}\end{array}$ & 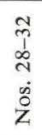 & $\begin{array}{l}\dot{0} \\
\tilde{m} \\
m \\
\dot{0} \\
\dot{0}\end{array}$ & $\begin{array}{l}\infty \\
0 \\
\frac{1}{m} \\
\dot{0} \\
\frac{0}{2}\end{array}$ & 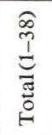 & $\frac{\vec{a}}{\frac{0}{0}}$ \\
\hline Attheya zachariasi J. Brun & . & . & 3 & 4 & 2 & . & . & . & . & . & . & . & 6 & $T$ \\
\hline Caloneis alpestris (Grun.) Cleve.. & . & . & . & 1 & . & . & . & . & . & . & . & . & 1 & \\
\hline - amphisbaena (Bory) Cleve ........ & . & 1 & 1 & . & 1 & . & . & . & 1 & 1 & 1 & . & 4 & + \\
\hline - bacillum (Grun.) Cleve........... & + & 1 & 14 & 3 & 1 & 1 & 2 & 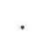 & . & 4 & 1 & 1 & 13 & + \\
\hline - - var. lancettula (Schulz) Hust. .... & $\cdot$ & . & - & . & 2 & . & . & . & . & . & . & . & 2 & 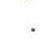 \\
\hline-- - forma $(I: 15) \ldots \ldots \ldots \ldots \ldots$ & . & . & . & . & 1 & . & . & 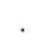 & . & . & . & . & 1 & \\
\hline - latiuscula (Küt & + & + & . & . & . & . & . & . & . & . & . & . & . & \\
\hline - schumanniana & + & . & . & 3 & . & 1 & . & . & . & . & 2 & . & 6 & $\cdot$ \\
\hline - - vat & . & 3 & . & . & 1 & . & . & . & . & . & . & 1 & 2 & \\
\hline - silicula (Ehr.) C & + & 3 & 11 & 4 & 5 & 1 & 1 & 1 & 1 & 3 & 2 & . & 18 & + \\
\hline - - var. alpina Cle & . & . & 1 & . & . & . & . & ${ }^{\circ}$ & . & . & . & . & . & . \\
\hline - - var. gibberula (Kütz.) Grun. ..... & . & . & . & 1 & . & 2 & . & . & . & 1 & . & . & 4 & \\
\hline - - var. truncatula Grun. ....... & . & . & . & . & 1 & . & . & . & 2 & 1 & 1 & 1 & 6 & . \\
\hline - - var. vent & . & . & - & . & . & . & . & . & . & 1 & . & . & 1 & \\
\hline Campylodiscus noricus Ehr. var. hiber- & & & & & & & & & & & & & & \\
\hline nica & + & 4 & . & 1 & 2 & . & 1 & 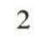 & . & . & . & . & 6 & + \\
\hline Cerato & . & . & 1 & . & . & . & . & . & . & . & . & . & . & \\
\hline $\mathrm{Cocc}$ & . & 7 & 29 & 5 & 3 & 2 & 2 & 1 & 4 & 1 & 4 & 2 & 24 & + \\
\hline$-d i$ & + & 2 & 6 & 3 & 2 & 1 & . & 1 & 4 & 2 & 2 & 1 & 6 & + \\
\hline - pediculus & . & 7 & . & 5 & 5 & 1 & 2 & 3 & 3 & 4 & 4 & 1 & 8 & + \\
\hline$r_{-}+2+2+2+2$ & + & 9 & 32 & 5 & 5 & 4 & 1 & 4 & 5 & 5 & 3 & 2 & 34 & + \\
\hline (Ehr.) Cleve & . & 4 & . & 3 & 4 & 5 & 3 & 3 & 5 & 3 & 2 & . & 28 & + \\
\hline _ - var. linea & + & 5 & . & . & 2 & 1 & . & . & 2 & 3 & . & . & 8 & + \\
\hline - scutellur & . & . & . & . & 1 & . & . & . & . & . & . & . & 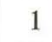 & \\
\hline - thum & . & . & 2 & 1 & 1 & 1 & 3 & 1 & 2 & 1 & 2 & . & 2 & + \\
\hline Cyclotella co & + & + & 5 & 5 & 5 & 5 & 3 & 4 & 5 & 5 & 4 & 2 & 38 & + \\
\hline - - var. oligo & . & . & . & . & . & 1 & . & . & . & . & . & . & & \\
\hline - kütz & + & 2 & 11 & 3 & 5 & 4 & 1 & 3 & 4 & 3 & 1 & 2 & 26 & + \\
\hline$--\mathrm{y}$ & . & 1 & 14 & 5 & 5 & 3 & . & 2 & 3 & 1 & 2 & 1 & 2 & + \\
\hline$--\mathrm{v}$ & + & 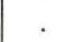 & 1 & 4 & 3 & 1 & . & 2 & 1 & 2 & 1 & 1 & 15 & + \\
\hline schumanni $\mathrm{C}$ & . & 10 & 28 & . & . & . & . & $\theta^{\circ}$ & . & . & . & . & & . \\
\hline - meneghiniana Kütz..... & + & . & + & 2 & 2 & 2 & . & . & 2 & 1 & . & 1 & 10 & . \\
\hline - ocellata $\mathrm{I}$ & . & . & . & 3 & 2 & 2 & . & 2 & . & . & . & . & 9 & + \\
\hline - operculata (Ag.) Kütz. . . & + & . & . & . & . & . & . & 1 & . & . & . & . & 1 & + \\
\hline - pseudostelligera Hust. . . . . & . & . & . & . & 1 & . & . & $\cdot$ & . & . & . & . & 1 & . \\
\hline - striata (Kütz.) Gr & . & . & 7 & . & . & . & . & . & . & . & . & . & . & . \\
\hline$--v$ & . & ${ }^{\circ}$ & 3 & . & . & . & . & . & . & . & . & . & . & . \\
\hline Cymatopleura elliptica & + & 8 & . & 2 & 4 & 2 & 2 & 2 & 1 & 2 & 4 & 2 & 21 & + \\
\hline - solea (Bréb.) W. & + & 9 & . & 4 & 5 & 5 & 3 & 3 & 4 & 5 & 4 & 1 & 34 & + \\
\hline Cymbella acuta A. Schmidt . & 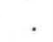 & . & + & . & . & . & . & . & . & . & . & . & . & . \\
\hline - aequalis E. Smith......... & + & . & 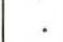 & . & - & . & . & $\cdot$ & . & - & . & . & & \\
\hline - affinis Kütz. & + & 8 & 17 & 5 & 4 & 4 & 1 & 2 & 3 & 4 & 1 & 1 & 25 & + \\
\hline - alpina Grun........ & + & . & 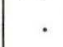 & . & ${ }^{\circ}$ & . & . & . & $\cdot$ & . & $\cdot$ & . & $\cdot$ & . \\
\hline - amphicephala Naegeli ... & . & & + & . & . & . & . & . & . & . & . & . & . & \\
\hline
\end{tabular}




\begin{tabular}{|c|c|c|c|c|c|c|c|c|c|c|c|c|c|c|}
\hline & \multirow[b]{2}{*}{ 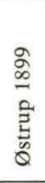 } & \multirow[b]{2}{*}{ 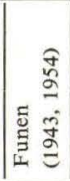 } & \multirow[b]{2}{*}{ 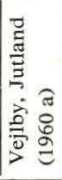 } & \multicolumn{10}{|c|}{ Hollerup } & \multirow[b]{2}{*}{$\frac{\mathrm{d}}{\mathrm{J}}$} \\
\hline & & & & $\begin{array}{l}\stackrel{n}{1} \\
\dot{p} \\
\dot{0} \\
Z\end{array}$ & $\begin{array}{l}\text { 음 } \\
b \\
\dot{0} \\
\dot{z}\end{array}$ & $\begin{array}{l}\frac{n}{1} \\
\beth \\
\dot{0} \\
\ddot{z}\end{array}$ & $\begin{array}{l}\frac{\infty}{b} \\
\underline{b} \\
\dot{0} \\
z\end{array}$ & $\begin{array}{l}\tilde{\pi} \\
\stackrel{2}{ } \\
\dot{0} \\
\dot{z}\end{array}$ & $\begin{array}{l}\hat{\tilde{a}} \\
\text { iे } \\
\dot{0} \\
\dot{0} \\
z\end{array}$ & 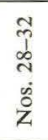 & $\begin{array}{l}0 \\
\tilde{m} \\
m \\
m \\
\dot{0} \\
z\end{array}$ & $\begin{array}{l}\infty \\
0 \\
i \\
0 \\
0 \\
\dot{0} \\
\dot{z} \\
\dot{z}\end{array}$ & 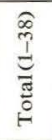 & \\
\hline Cymbella angustata (W.Smith) Cleve... & + & . & . & . & . & . & . &. & . & . & . & . & . & . \\
\hline - aspera (Ehr.) Cleve ............ & + & 5 & 5 & 2 & 1 & . & 2 & . & 1 & 3 & 4 & . & 13 & + \\
\hline - austriaca Grun. var. densestriata & & & & & & & & & & & & & & \\
\hline Østrup ............ & . & . & + & . & . & . & . & . & . & . & . & . & . & . \\
\hline - cesati (Rabh.) Grun.............. & . & . & 1 & . & . & . & . & . & . & . & . & . & . & . \\
\hline - cistula (Hempr.) Grun............ & + & 9 & 26 & 5 & 5 & 3 & 2 & 4 & 4 & 5 & 4 & 2 & 34 & + \\
\hline - - var. maculata (Kütz.) van Heurck & + & . & 1 & . & . & . & . & . & . & . & . & . & . & . \\
\hline - cuspidata Kütz. .............. & + & 7 & 12 & 1 & 1 & . & . & . & 1 & 2 & 2 & . & 7 & . \\
\hline - cymbiformis (Ag.? Kütz.) van Heurck & + & . & 2 & . & 1 & 1 & . & 1 & . & . & . & . & 3 & + \\
\hline - ehrenbergii Küitz................. & + & 9 & 1 & 2 & 4 & 2 & 3 & 1 & 3 & 4 & 4 & 1 & 24 & + \\
\hline - gracilis (Rabh.) Cleve............. & . & . & . & . & . & . & . & . & 1 & . & . & . & 1 & . \\
\hline - hebridica (Greg.) Grun. .......... & . & . & 13 & . & . & . & . & . & . & . & . & . & . & . \\
\hline - helvetica Kütz............. & + & 6 & 15 & 4 & 4 & 3 & 2 & . & 1 & 1 & . & 1 & 16 & + \\
\hline - - var. compacta (Østrup) Hust. .... & . & . & . & 1 & . & . & . & . & . & . & . & . & 1 & . \\
\hline - hustedtii Krasske ............... & . & . & . & 1 & 1 & . & . & . & . & . & . & . & 2 & . \\
\hline - lacustris (Ag.) Cleve .......... & + & 1 & . & . & . & . & . & . & . & . & . & . & . & . \\
\hline - laevis Naegeli ............. & . & 1 & . & . & . & . & . & . & . & . & . & . & . & + \\
\hline - lanceolata (Ehr.) van Heurck . . & + & 10 & 14 & 5 & 4 & 3 & 2 & 3 & 4 & 5 & . & . & 26 & + \\
\hline- lata Grun................ & + & . & . & . & . & . & . & . & . & . & . & . & . & . \\
\hline - leptoceros (Ehr.?) Grun....... & + & 10 & . & 1 & . & 1 & . & . & . & . & . & . & 2 & + \\
\hline - microcephala Grun........ & . & . & . & . & 1 & . & . & . & . & . & . & . & 1 & . \\
\hline - naviculiformis Auerswald ...... & + & + & 1 & 2 & . & . & 1 & . & 1 & 2 & 1 & . & 7 & . \\
\hline - obtusa Gregory ......... & + & 3 & 4 & 1 & . & . & . & . & . & 1 & 1 & 1 & 4 & . \\
\hline - parva (W. Smith) Cleve .......... & . & . & 1 & . & . & . & . & . & 1 & . & . & . & 1 & . \\
\hline - perpusilla A. Cleve.......... & . & . & 1 & . & . & . & 1 & . & . & . & 1 & . & 2 & . \\
\hline - prostrata (Berkeley) Cleve ..... & + & 5 & 19 & 1 & 5 & 1 & . & . & . & . & . & . & 7 & + \\
\hline - reinhardtii Grun........... & . & . & . & 3 & 1 & . & . & . & . & 1 & 1 & . & 6 & . \\
\hline - sinuata Gregory......... & + & 2 & 29 & 4 & 2 & . & 2 & . & . & 3 & 4 & . & 15 & + \\
\hline - tumida (Bréb.) van Heurck .... & . & . & . & 2 & 1 & . & . & 1 & 2 & . & . & . & 6 & . \\
\hline - thumensis (A. Mayer) Hust.. & . & . & . & 1 & . & . & . & . & . & . & . & . & 1 & . \\
\hline - tumidula Grun............. & . & . & . & 1 & . & 1 & 1 & . & 2 & 2 & . & . & 7 & + \\
\hline - turgida (Greg.) Cleve .... & . & 7 & 27 & 4 & 2 & 3 & 1 & . & 1 & 5 & 3 & 1 & 20 & + \\
\hline - ventricosa Kütz............ & + & 9 & 26 & 5 & 4 & 5 & 3 & 4 & 4 & 5 & 4 & 1 & 35 & + \\
\hline Cymbellonitzschia diluviana Hust...... & . & . & 12 & . & . & . & 1 & . & . & . & 3 & . & 4 & . \\
\hline Denticula tenuis Kütz. . . . . . . . . . . . & . & . & 2 & . & . & . & . & . & . & . & . & . & . & . \\
\hline Diatoma elongatum Agardh...... & . & . & . & 3 & 1 & . & 2 & . & 1 & . & 1 & . & 8 & . \\
\hline - - var. tenuis (Ag.) Kütz. . . . & + & . & . & . & . & 1 & 1 & . & . & . & . & . & 2 & . \\
\hline - vulgare Bory.......... & . & . & . & 3 & . & 1 & . & . & . & 1 & 2 & . & 7 & . \\
\hline - - var. producta Grun.......... & . & . & . & . & 2 & . & . & . & . & 1 & 1 & . & 4 & . \\
\hline Diploneis domblittensis (Grun.) Cleve.. & + & + & . & . & . & . & . & . & . & . & . & . & . & . \\
\hline - - var. subconstricta A. Cleve. & + & + & . & . & 2 & . & . & . & . & . & . & . & 2 & . \\
\hline - elliptica (Kütz.) Cleve. . . . . & + & . & 11 & 1 & 3 & 2 & 1 & 1 & 1 & 2 & 2 & . & 13 & + \\
\hline - interrupta (Kütz.) Cleve .. & . & 1 & . & . & . & . & . & . & . & . & . & . & . & . \\
\hline - mauleri (Brun) Cleve.... & - & + & . & . & . & . & . & . & . & . & . & . & . & . \\
\hline
\end{tabular}




\begin{tabular}{|c|c|c|c|c|c|c|c|c|c|c|c|c|c|c|}
\hline & \multirow[b]{2}{*}{ 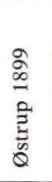 } & \multirow[b]{2}{*}{ 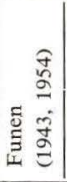 } & \multirow{2}{*}{ 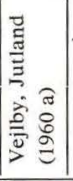 } & \multicolumn{10}{|c|}{ Hollerup } & \multirow[b]{2}{*}{$\frac{\frac{3}{2}}{3}$} \\
\hline & & & & $\begin{array}{l}n \\
\stackrel{1}{1} \\
\dot{0} \\
\dot{0}\end{array}$ & $\begin{array}{l}\stackrel{0}{b} \\
\dot{b} \\
\dot{0} \\
\dot{z}\end{array}$ & $\begin{array}{l}\stackrel{\sim}{I} \\
\underline{z} \\
\dot{0} \\
z\end{array}$ & $\begin{array}{l}\infty \\
\frac{1}{b} \\
\dot{0} \\
\dot{0} \\
z\end{array}$ & $\begin{array}{l}\tilde{J} \\
\text { gे } \\
\dot{0} \\
z \\
z\end{array}$ & $\begin{array}{l}\hat{A} \\
\tilde{\lambda} \\
\dot{0} \\
\dot{0} \\
z\end{array}$ & 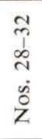 & $\begin{array}{l}0 \\
\tilde{j} \\
m \\
m \\
\dot{0} \\
\dot{z}\end{array}$ & 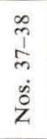 & 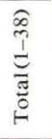 & \\
\hline Diploneis oculata (Bréb.) Cleve ...... & . & . & . & 3 & 2 & . & . & . & 1 & 1 & 1 & . & 8 & . \\
\hline - ovalis (Hilse) Cleve ............. & . & 8 & 19 & 5 & 3 & 2 & 2 & . & 3 & 2 & 1 & 2 & 20 & . \\
\hline - - var. oblongella (Naegeli) Cleve... & . & 1 & . & . & . & . & . & . & . & . & . & . & . & . \\
\hline - puella (Schum.) Cleve........... & . & 1 & 2 & 1 & . & . & 1 & . & . & 1 & . & 1 & 4 & + \\
\hline - smithii (Bréb.) Cleve var. pumila & & & & & & & & & & & & & & \\
\hline (Grun.) Hust.............. & + & . & . & . & . & . & . & . & . & . & . & . & . & . \\
\hline Epithemia argus Kütz............. & + & . & 1 & . & . & . & . & . & . & . & . & . & . & . \\
\hline - hyndmanni W. Smith............. & . & 8 & 27 & 4 & 5 & 1 & 2 & 2 & 4 & 3 & 3 & 1 & 25 & + \\
\hline - intermedia Fricke.............. & . & 1 & 1 & 1 & 2 & 1 & . & . & 1 & 1 & 2 & . & 8 & + \\
\hline - sorex Kütz............... & + & 8 & 27 & 5 & 5 & 5 & 3 & 4 & 5 & 5 & 4 & 2 & 38 & + \\
\hline - - var. gracilis Hust. . ........... & . & . & . & 2 & . & 1 & . & . & . & . & . & . & 3 & + \\
\hline - turgida (Ehr.) Kütz. . . . . . . . . . & + & 5 & 5 & 3 & 5 & 4 & 3 & 4 & 5 & 4 & 2 & 1 & 31 & + \\
\hline - - var. granulata (Ehr.) Grun. ...... & . & . & . & 2 & 3 & 1 & 1 & . & 1 & 2 & 1 & . & 11 & + \\
\hline - zebra (Ehr.) Kütz............ & + & 5 & 24 & 5 & 4 & 5 & 3 & 3 & 4 & 3 & 3 & 2 & 32 & + \\
\hline - - var. porcellus (Kütz.) Grun....... & . & 3 & 5 & . & 1 & . & . & . & . & . & . & . & 1 & + \\
\hline - - var. saxonica (Kütz.) Grun...... & . & 4 & 30 & 5 & 3 & 5 & 2 & 4 & 5 & 5 & 2 & 2 & 33 & + \\
\hline Eunotia arcus Ehr............... & + & + & . & . & . & . & . & . & . & . & . & . & . & + \\
\hline - - var. bidens Grun.............. & . & . & . & . & 1 & . & . & . & . & . & . & . & 1 & . \\
\hline - flexuosa Kütz. ...... & . & . & 1 & . & . & . & . & . & . & . & . & . & . & . \\
\hline - gracilis (Ehr.) Rabh....... & . & 2 & . & 3 & . & . & 1 & . & . & . & . & 1 & 5 & . \\
\hline - lunaris (Ehr.) Grun. . . . . . . . . & . & 1 & . & 1 & 1 & . & 1 & 1 & . & 1 & . & 1 & 6 & + \\
\hline - - var. subarcuata (Naeg.) Grun .... & . & . & . & . & . & . & . & . & . & . & 1 & . & 1 & . \\
\hline - monodon Ehr. var. bidens (Greg.) & & & & & & & & & & & & & & \\
\hline W. Smith............... & . & . & 2 & . & . & . & . & . & . & . & . & . & . & . \\
\hline - - var. maior (W. Smith) Hust. ..... & + & . & . & . & . & . & . & . & . & . & . & . & . & . \\
\hline - parallela Ehr. ............. & + & . & . & . & 1 & . & . & . & . & . & . & . & 1 & . \\
\hline - pectinalis (Kütz.) Rabh........... & + & 1 & 2 & . & . & . & . & . & . & . & . & . & . & . \\
\hline - - var. minor (Kütz.) Rabh. ........ & . & 1 & 4 & . & . & . & . & . & . & 1 & . & . & 1 & . \\
\hline - - - fo. impressa Ehr.... & . & . & 2 & . & . & . & . & . & . & . & . & . & . & . \\
\hline - praerupta Ehr. ............ & . & . & 1 & . & . & . & . & . & . & 1 & 1 & . & 2 & . \\
\hline - sudetica (O. Müller) Hust. .... & . & . & 2 & 1 & . & . & . & . & 1 & . & . & . & 2 & . \\
\hline - tenella (Grun.) Hust........... & . & 1 & . & . & . & . & . & . & . & . & . & . & . & . \\
\hline - triodon Ehr. .............. & . & . & 2 & . & . & . & . & . & . & . & . & . & . & . \\
\hline - veneris (Kütz.) O. Müller..... & . & . & 3 & . & 1 & . & . & . & . & . & 1 & . & 2 & . \\
\hline Fragilaria bicapitata A. Mayer ... & . & . & 1 & . & 2 & . & . & . & . & . & 1 & . & 3 & + \\
\hline - bidens Heiberg........ & + & 8 & . & 2 & 1 & . & . & . & . & 1 & 1 & . & 5 & + \\
\hline - brevistriata Grun. ...... & + & 1 & 10 & . & . & . & . & . & . & . & . & . & . & . \\
\hline - capucina Desmaz. . . . . . . . . . . & + & 2 & 19 & 4 & 3 & 3 & 1 & . & 3 & 2 & 2 & . & 18 & + \\
\hline - - var. acuta (Ehr.) Rabh. . & + & . & . & . & . & . & . & . & . & . & . & . & . & . \\
\hline - - var. lanceolata Grun. ...... & + & . & . & . & . & . & . & . & . & . & . & . & . & . \\
\hline - - var. mesolepta (Rabh.) Grun. .... & . & 3 & 2 & 1 & 1 & . & . & . & . & . & 2 & . & 4 & . \\
\hline - construens (Ehr.) Grun. ...... & + & 10 & 24 & 5 & 5 & 5 & 3 & 4 & 5 & 5 & 4 & 2 & 38 & + \\
\hline - - var. binodis (Ehr.) Grun. .... & . & 9 & 19 & 4 & 4 & 4 & 3 & 4 & 4 & 5 & 4 & 2 & 34 & + \\
\hline - - var. subsalina Hust............. & . & 5 & 7 & . & 1 & . & . & 1 & 3 & 2 & 2 & 1 & 10 & 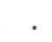 \\
\hline
\end{tabular}




\begin{tabular}{|c|c|c|c|c|c|c|c|c|c|c|c|c|c|c|}
\hline & \multirow[b]{2}{*}{ 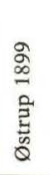 } & \multirow[b]{2}{*}{ 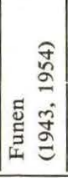 } & \multirow[b]{2}{*}{ 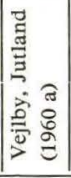 } & \multicolumn{10}{|c|}{ Hollerup } & \multirow[b]{2}{*}{$\frac{\frac{\partial}{2}}{3}$} \\
\hline & & & & 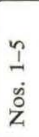 & $\begin{array}{l}\stackrel{0}{]} \\
b \\
\dot{0} \\
z \\
z\end{array}$ & $\begin{array}{l}\frac{n}{1} \\
= \\
\dot{0} \\
\dot{z}\end{array}$ & 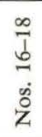 & $\begin{array}{l}\tilde{J} \\
\dot{J} \\
\dot{0} \\
\dot{0} \\
z\end{array}$ & 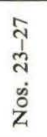 & 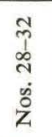 & $\begin{array}{l}\stackrel{0}{0} \\
\text { m. } \\
\dot{m} \\
\dot{0} \\
\text { z. }\end{array}$ & $\begin{array}{l}\infty \\
\stackrel{1}{1} \\
\tilde{n} \\
\dot{0} \\
\dot{0} \\
\dot{Z}\end{array}$ & 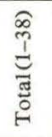 & \\
\hline \multicolumn{15}{|l|}{ Fragilaria construens var. triundulata } \\
\hline Reichelt & + & 10 & . & 4 & 5 & 5 & 3 & 4 & 5 & 2 & 4 & 2 & 34 & + \\
\hline - - var, venter (Ehr.) Grun... & . & 8 & 14 & 5 & 5 & 5 & 3 & 3 & 5 & 4 & 3 & 2 & 35 & + \\
\hline - crotonensis Kitton.............. & . & 7 & 6 & 5 & 4 & . & . & . & . & . & 1 & . & 10 & . \\
\hline - inflata (Heid.) Hust. . . . . . . & . & . & . & $\cdot$ & 1 & . & 1 & . & . & 1 & 2 & . & 5 & . \\
\hline - intermedia Grun. .............. & + & . & + & 1 & 1 & . & 2 & 3 & 1 & 2 & 2 & 1 & 13 & . \\
\hline - lapponica Grun...... & . & . & . & 5 & 5 & 5 & 3 & 4 & 5 & 4 & 1 & 2 & 34 & + \\
\hline - leptostauron (Ehr.) Hust. . & + & + & 7 & . & . & . & 1 & . & . & 2 & 3 & . & 6 & + \\
\hline - - var. dubia Grun. . ............ & . & + & . & . & . & . & . & . & 1 & . & . & . & 1 & + \\
\hline - pinnata Ehr. ............ & . & 8 & 8 & 1 & . & . & 1 & . & . & 1 & 2 & . & 5 & . \\
\hline - - var. intercedens Grun........... & + & $\cdot$ & . & $\cdot$ & . & . & . & . & . & . & . & . & . & . \\
\hline - - var. lancettula (Schum.) Hust.... . & . & + & . & . & . & . & . & . & . & . & . & . & . & . \\
\hline - vaucheriae (Kütz.) Boye Petersen ... & . & 9 & 16 & 2 & 4 & 3 & 1 & . & . & 1 & 3 & 1 & 15 & + \\
\hline - virescens Ralfs ............... & . & 4 & 23 & 1 & . & 3 & 3 & 3 & 3 & 2 & 1 & . & 16 & + \\
\hline - - var. capitata Krasske ..... & . & 2 & . & . & . & . & . & . & . & . & . & . & . & . \\
\hline - - var. elliptica Hust.......... & $\cdot$ & 6 & . & 1 & . & 1 & $\cdot$ & . & $\cdot$ & $\cdot$ & . & . & 2 & + \\
\hline - - var. subsalina Grun. ....... & . & 6 & . & . & . & . & . & . & . & . & 1 & . & 1 & . \\
\hline Frustulia rhomboides (Ehr.) De Toni .. & . & $\cdot$ & 1 & . & . & . & . & . & . & . & . & . & . & . \\
\hline - - var. saxonica (Rabh.) De Toni... & + & . & 1 & . & . & . & . & . & . & . & . & . & . & . \\
\hline - vulgaris Thwaites............... & . & . & . & . & . & . & . & . & . & . & 1 & . & 1 & . \\
\hline Gomphocymbella ancyli Hust. ... & . & . & + & . & . & 1 & . & . & . & . & . & . & 1 & . \\
\hline Gomphonema acuminatum Ehr. ...... & + & 5 & 7 & 5 & 2 & 1 & 1 & 1 & 3 & 5 & 2 & . & 20 & + \\
\hline - - var. brébissonii (Kütz.) Cleve..... . & . & 8 & 6 & 2 & 5 & 4 & 2 & 2 & 3 & 3 & 3 & 1 & 25 & + \\
\hline - - var. coronata (Ehr.) W. Smith.... & + & + & 1 & . & 3 & 1 & 2 & . & 1 & 1 & . & . & 8 & . \\
\hline - - var. trigonocephala (Ehr.) Grun... & . & 3 & 11 & 1 & 1 & 2 & . & 1 & 1 & 1 & 2 & . & 9 & + \\
\hline - - var. turris (Ehr.) Cleve .......... & . & 8 & . & 2 & 1 & 1 & . & $\cdot$ & 1 & $\cdot$ & . & . & 5 & + \\
\hline-- fo. $(V: 8) \ldots \ldots \ldots$ & . & . & . & . & . & . & . & 1 & . & . & . & . & 1 & . \\
\hline - angustatum (Kütz.) Rabh. ... & + & 8 & 3 & 3 & 2 & 4 & 1 & 2 & 3 & 3 & 1 & 1 & 20 & . \\
\hline - - var. producta Grun............. & . & 2 & . & . & . & . & . & . & . & . & . & . & . & + \\
\hline - augur Ehr............ & + & - & . & . & . & . & . & . & . & · & . & . & . & · \\
\hline - - var. gautieri van Heurck .. & . & . & . & . & 1 & . & . & . & 1 & 1 & . & 1 & 4 & - \\
\hline - bohemicum Reichelt \& Fricke.. & . & . & 1 & . & . & . & . & . & . & . & . & . & . & 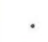 \\
\hline - constrictum Ehr............. & - & . & 4 & 4 & 4 & 2 & 1 & 2 & 2 & 4 & . & 1 & 20 & + \\
\hline - - var. capitata (Ehr.) Cleve... . & + & 10 & 25 & 2 & 4 & 3 & 2 & 1 & 3 & 5 & 2 & 1 & 23 & + \\
\hline - gracile Ehr............. & + & 1 & 8 & 3 & 2 & 4 & 2 & 2 & 1 & 4 & 1 & 1 & 20 & + \\
\hline - intricatum Kütz.......... & + & 4 & . & 3 & 3 & 2 & 1 & 1 & 1 & 1 & 1 & . & 13 & + \\
\hline - - var. dichotoma (Kütz.) Grun. ... . & . & . & 3 & 3 & . & 1 & 3 & 2 & 4 & 3 & 2 & . & 18 & + \\
\hline - - var. vibrio (Ehr.) Cleve.......... & + & . & . & . & . & . & . & . & . & . & . & . & . & 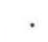 \\
\hline - - var. pumila Grun. ........ & - & . & . & . & . & . & . & . & 1 & . & . & . & 1 & . \\
\hline - lanceolatum Ehr.......... & . & 7 & 7 & 2 & 3 & 3 & 1 & . & 1 & 4 & 1 & 1 & 16 & + \\
\hline - - var. insignis (Greg.) Cleve. & + & - & - & - & . & 1 & ${ }^{\circ}$ & . & . & 1 & 1 & - & 3 & 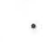 \\
\hline 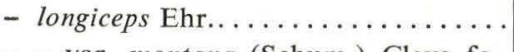 & - & 1 & . & 1 & . & . & . & . & . & . & . & . & 1 & + \\
\hline $\begin{array}{c}\text { - - var. montana (Schum.) Cleve fo. } \\
\text { suecica Grun. . . . . . . . . . . . }\end{array}$ & 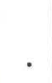 & ${ }^{\circ}$ & $\cdot$ & 1 & . & $\cdot$ & 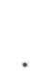 & - & $\cdot$ & 1 & . & - & 2 & + \\
\hline - - var. subclavata Grun. .......... & - & 2 & . & 1 & . & . & . & . & . & . & - & . & 1 & + \\
\hline
\end{tabular}




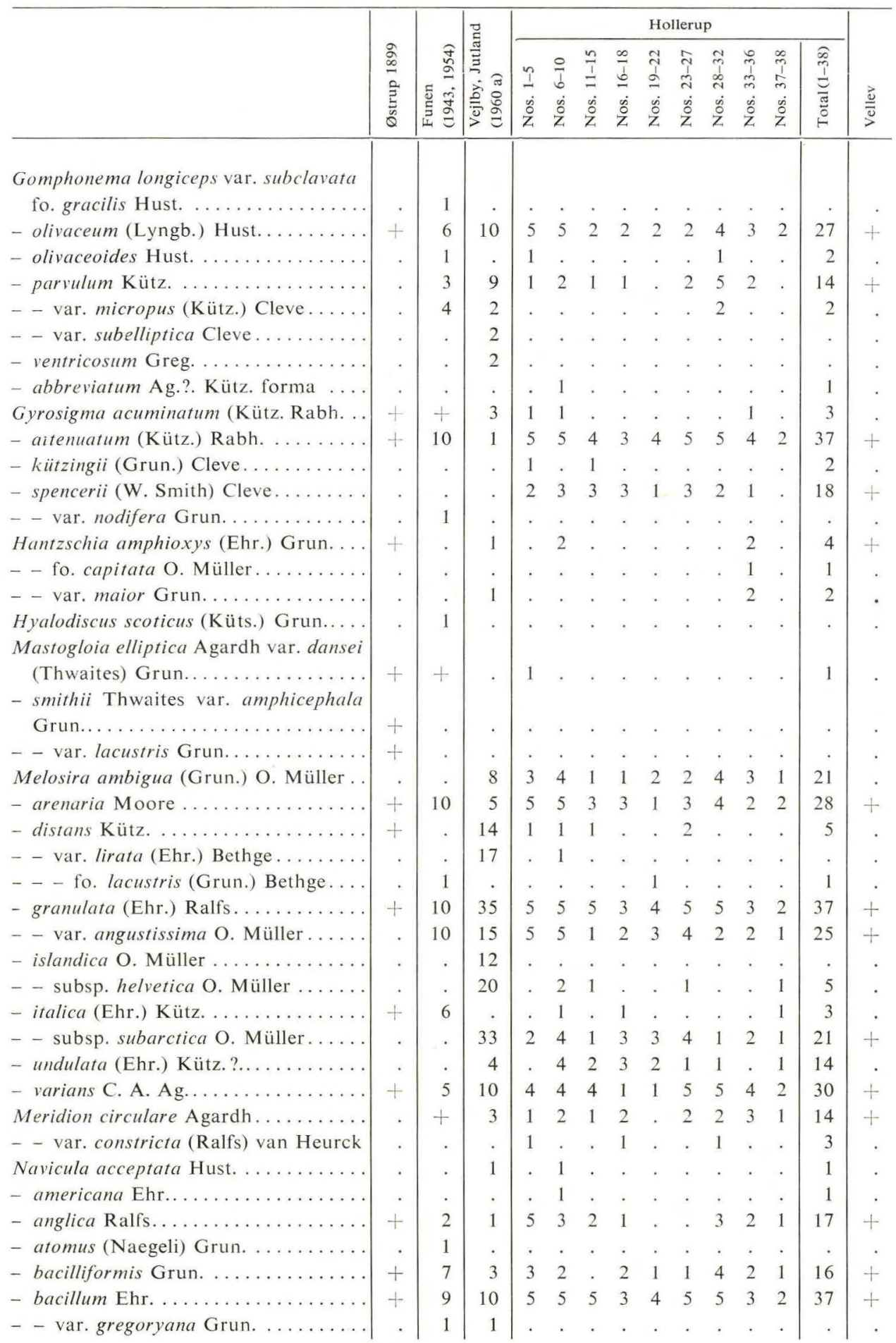




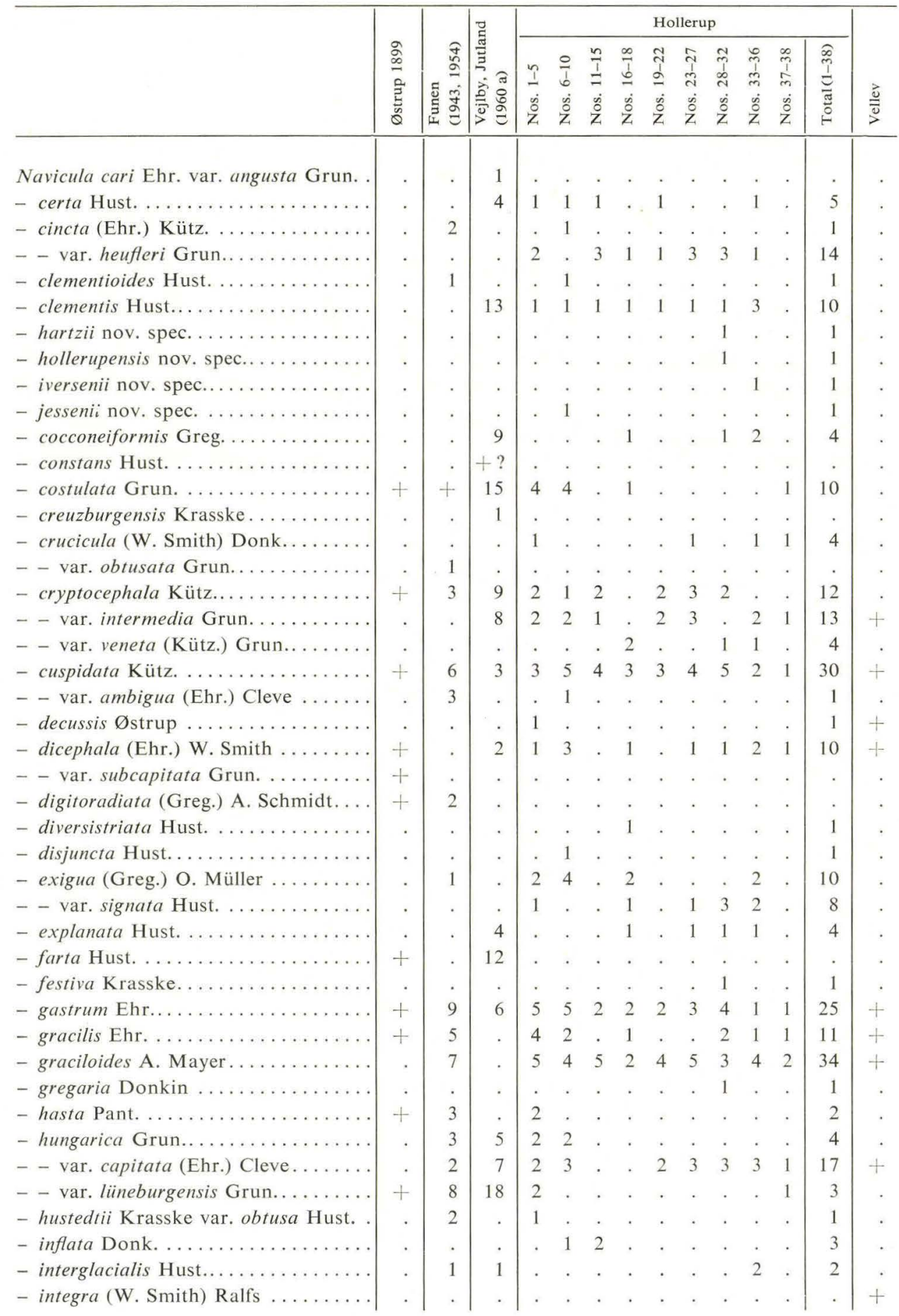




\begin{tabular}{|c|c|c|c|c|c|c|c|c|c|c|c|c|c|c|}
\hline & \multirow[b]{2}{*}{ 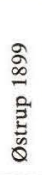 } & \multirow[b]{2}{*}{ 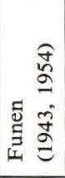 } & \multirow[b]{2}{*}{ 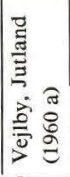 } & \multicolumn{10}{|c|}{ Hollerup } & \multirow[b]{2}{*}{$\frac{\vec{d}}{\bar{v}}$} \\
\hline & & & & $\begin{array}{l}n \\
\stackrel{n}{1} \\
\dot{0} \\
\dot{Z}\end{array}$ & $\begin{array}{l}0 \\
b \\
b \\
\dot{0} \\
z\end{array}$ & $\begin{array}{l}\frac{n}{I} \\
= \\
\dot{0} \\
z\end{array}$ & $\begin{array}{l}\frac{\infty}{\bar{b}} \\
\dot{0} \\
\stackrel{8}{z}\end{array}$ & $\begin{array}{l}\tilde{N} \\
\stackrel{d}{\alpha} \\
\dot{\delta} \\
\dot{z}\end{array}$ & $\begin{array}{l}\tilde{T} \\
\tilde{n} \\
\dot{d} \\
\dot{z}\end{array}$ & 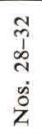 & $\begin{array}{l}0 \\
\tilde{n} \\
\tilde{m} \\
\dot{m} \\
\dot{8} \\
z\end{array}$ & 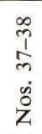 & 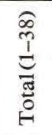 & \\
\hline Navicula jentzschii Grun. .......... & + & 3 & 10 & . & . & . & 1 & . & . & 1 & 3 & . & 5 & . \\
\hline - järnefelti Hust................. & . & . & 26 & . & . & . & 1 & . & . & . & 3 & . & 4 & . \\
\hline - lacustris Greg. ................. & . & . & 3 & . & . & . & 1 & . & . & . & . & . & 1 & . \\
\hline - lagerstedtii Cleve var. palustris Hust. & . & . & + & . & . & . & 1 & . & . & . & . & 1 & 2 & . \\
\hline - lanceolata (Ag.) Kütz............. & + & 4 & 1 & 5 & 4 & 1 & . & 2 & 1 & 4 & 2 & 1 & 20 & + \\
\hline - laterostrata Hust............... & . & 1 & . & 2 & 4 & 1 & 2 & 1 & . & 2 & . & 1 & 13 & + \\
\hline - menisculus Schum......... & . & 4 & 6 & 2 & 1 & . & . & . & . & 1 & 1 & 1 & 6 & + \\
\hline - - var. obtusa Hust. . . . . . . . . . . & . & 4 & 5 & . & . & . & 1 & . & . & . & . & . & 1 & . \\
\hline - mentzii nov. spec. ............ & . & . & . & 1 & 2 & . & . & 1 & . & . & . & . & 4 & . \\
\hline - milthersii nov. spec........... & . & . & . & . & . & . & . & . & . & . & 1 & . & 1 & . \\
\hline - meniscus Schum. .............. & . & . & . & 2 & 2 & . & . & . & 1 & 2 & 1 & . & 8 & + \\
\hline - minuscula Grun................ & . & 1 & . & . & . & . & . & . & . & . & . & . & . & . \\
\hline - modica Hust. ................. & . & 1 & . & . & . & . & 1 & . & . & 1 & . & . & 2 & . \\
\hline - mutica Kütz.................. & . & . & . & . & . & 1 & . & . & . & . & . & . & 1 & . \\
\hline - oblonga Kütz............. & + & 9 & 1 & 4 & 5 & 5 & 3 & 3 & 3 & 5 & 4 & 2 & 34 & + \\
\hline - opportuna Hust................ & . & . & 2 & . & . & . & . & . & . & . & . & . & . & . \\
\hline - oppugnata Hust.............. & . & 9 & 10 & 5 & 5 & 4 & 2 & 2 & 5 & 3 & 1 & 1 & 28 & + \\
\hline - paludosa Hust. ........... & + & . & 1 & . & . & . & . & . & . & $\cdot$ & . & . & . & . \\
\hline - peregrina Ehr. ...... & . & 2 & . & . & . & . & . & . & . & . & . & . & . & . \\
\hline - - var. meniscus Schum. ... . & + & . & . & . & . & . & . & . & . & . & . & . & . & . \\
\hline - - var. menisculus Schum... . & + & . & . & . & . & . & . & . & . & . & . & . & . & . \\
\hline - placentula (Ehr.) Grun......... & . & 3 & 5 & 2 & 1 & 1 & 2 & 1 & 3 & 2 & . & 2 & 14 & + \\
\hline - - var. jenisseyensis (Grun.). & . & . & . & . & . & . & 2 & 1 & . & . & 1 & . & 4 & . \\
\hline - - var. latiuscula (Grun.) Meister... & . & 3 & . & 2 & 2 & . & . & . & 1 & 3 & 1 & . & 9 & . \\
\hline - - var. rostrata (Mayer) .... & . & 5 & 4 & 2 & 2 & 2 & 2 & 2 & 4 & 3 & 1 & 1 & 19 & + \\
\hline - protracta Grun........... & . & 3 & . & . & . & 1 & . & 1 & 1 & . & . & . & 3 & . \\
\hline - pseudobacillum Grun. .... . & . & . & + & . & . & . & . & . & . & . & 1 & . & 1 & . \\
\hline - pseudoscutiformis Hust. ... & . & . & 13 & . & . & . & 1 & . & . & 2 & 4 & . & 7 & . \\
\hline - pseudotuscula Hust........ & . & 1 & 4 & 3 & 2 & . & 1 & . & . & . & 1 & . & 7 & + \\
\hline - pupula Kütz............. & + & 5 & 10 & 4 & 5 & 3 & 3 & 2 & 4 & 4 & 4 & 1 & 30 & + \\
\hline - - var. capitata Hust....... & . & 4 & 1 & 1 & 3 & 3 & 1 & 1 & . & 1 & 1 & 1 & 12 & + \\
\hline - - var. rectangularis (Greg.) Grun. .. & . & 1 & . & 1 & . & . & . & . & 1 & 1 & . & . & 3 & + \\
\hline - - var. hollerupensis nov. var... & . & . & . & . & . & . & . & . & . & . & 1 & . & 1 & - \\
\hline - radiosa Kütz. ............ & + & 6 & 15 & 5 & 4 & 3 & 3 & 2 & 3 & 5 & 3 & . & 28 & + \\
\hline - reinhardtii Grun. ........ & + & 10 & 6 & 3 & 3 & . & 1 & . & . & 2 & 3 & 1 & 13 & + \\
\hline - rotaeana (Rabh.) Grun. .. & . & 1 & . & . & . & . & . & . & . & . & 2 & . & 2 & . \\
\hline - rotunda Hust.......... & . & . & 3 & 1 & . & 1 & . & . & . & . & 1 & . & 3 & . \\
\hline - rhynchocephala Kütz. . . & + & . & . & . & 2 & . & 2 & . & . & 2 & 2 & . & 8 & . \\
\hline - salinarum Grun......... & . & 1 & . & . & . & . & . & . & . & . & . & . & . & . \\
\hline - schönfeldii Hust. . ..... & . & 8 & 26 & 5 & 5 & 5 & 2 & 4 & 5 & 4 & 2 & 2 & 34 & + \\
\hline - scutelloides W. Smith ... & + & 5 & 15 & 5 & 3 & 1 & 2 & 3 & 3 & 2 & 3 & 2 & 24 & + \\
\hline - similis Krasske....... & . & - & . & . & . & . & ${ }^{\circ}$ & . & . & . & . & 1 & 1 & . \\
\hline - subhamulata Grun. ... & . & . & . & 1 & . & . & . & . & . & . & . & . & 1 & . \\
\hline - - var. undulata Hust. ..... & . & . & . & . & 2 & . & $\cdot$ & . & . & . & . & . & 2 & . \\
\hline
\end{tabular}




\begin{tabular}{|c|c|c|c|c|c|c|c|c|c|c|c|c|c|c|}
\hline & & & & & & & & Hol & 11eru & & & & & \\
\hline & 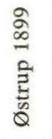 & 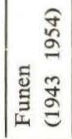 & 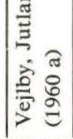 & $\begin{array}{l}n \\
\stackrel{1}{1} \\
\dot{0} \\
z\end{array}$ & $\begin{array}{l}\circ \\
\mathfrak{b} \\
\text { do } \\
\text { z }\end{array}$ & $\begin{array}{l}\stackrel{n}{I} \\
= \\
\dot{0} \\
\text { ż }\end{array}$ & 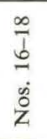 & $\begin{array}{l}\text { ה̃ } \\
\text { oे } \\
\dot{0} \\
\dot{z}\end{array}$ & $\begin{array}{l}\hat{i} \\
\text { iे } \\
\dot{0} \\
\dot{0} \\
\dot{z}\end{array}$ & $\begin{array}{l}\tilde{n} \\
0 \\
\text { iे } \\
\dot{0} \\
\dot{0} \\
z\end{array}$ & $\begin{array}{l}0 \\
\text { D } \\
m \\
m \\
\dot{b} \\
\dot{0} \\
\dot{z}\end{array}$ & 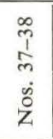 & 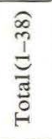 & $\frac{\vec{a}}{\frac{0}{0}}$ \\
\hline Navicula subrotundata Hust. . . . . . . . & . & 1 & . & . & 2 & 1 & 1 & . & . & 3 & . & . & 7 & . \\
\hline - tuscula Ehr. ................... & + & 6 & 26 & 4 & 2 & 1 & 1 & 1 & 1 & 1 & 4 & 1 & 16 & + \\
\hline - - fo. minor Hust. ............. & . & 6 & 30 & 4 & 2 & 2 & 2 & 2 & 2 & 3 & 4 & 1 & 22 & + \\
\hline - variostriata Krasske ............ & . & . & 1 & . & . & 3 & 3 & 4 & 3 & . & . & . & 13 & + \\
\hline - ventralis Kütz. ................. & . & . & 1 & . & . & . & . & . & . & . & . & . & . & . \\
\hline - viridula Kütz............ & . & 4 & 3 & 2 & 1 & . & 1 & 2 & 4 & 3 & 3 & . & 16 & . \\
\hline - - var. radians $\varnothing$ strup ......... & + & . & . & . & . & . & . & . & . & . & . & . & . & . \\
\hline - vulpina Kütz. . . . . . . . . . . & + & 3 & . & 3 & 5 & 3 & 3 & 3 & 3 & 4 & 2 & 1 & 27 & + \\
\hline - vitabunda Hust. ............... & . & . & . & . & . & . & . & . & 1 & . & . & . & 1 & . \\
\hline - vaucheriae Boye Petersen .......... & . & . & . & . & 1 & . & . & . & . & . & . & . & 1 & . \\
\hline - vaupellii nov. spec. .......... & . & . & . & . & . & . & . & . & . & . & 1 & . & 1 & . \\
\hline - warmingii nov. spec. ......... & . & . & . & . & 1 & . & . & . & . & . & 1 & . & 2 & . \\
\hline - sp. (III : 7) $\ldots \ldots \ldots \ldots \ldots \ldots$ & . & . & . & . & . & . & . & . & . & 1 & . & . & 1 & . \\
\hline- sp. (IV: 13). . . . . . . . . & . & . & . & . & 1 & . & . & . & . & . & . & . & 1 & . \\
\hline Neidium affine (Ehr.) Cleve var. & & & & & & & & & & & & & & \\
\hline amphirhynchus (Ehr.) Cleve... & . & . & . & . & 1 & . & . & . & . & 1 & . & . & 2 & . \\
\hline - binodis (Ehr.) Hust........... & . & . & . & . & 1 & . & . & . & . & . & . & . & 1 & . \\
\hline - bisulcatum (Lagerst.) Cleve ........ & + & . & . & . & . & . & . & . & . & . & . & . & . & . \\
\hline - dubium (Ehr.) Cleve ....... & + & 3 & . & 4 & 5 & 1 & 2 & 1 & 3 & 2 & 2 & 2 & 22 & + \\
\hline - iridis (Ehr.) Cleve ....... & + & 3 & 3 & 2 & 3 & 2 & 1 & 1 & 1 & 1 & . & 1 & 12 & + \\
\hline - - fo. vernalis Reichelt......... & . & 4 & . & 2 & 2 & 2 & . & 2 & 1 & 2 & 1 & 1 & 13 & + \\
\hline - - var. amphigomphus (Ehr.) van & & & & & & & & & & & & & & \\
\hline Heurck . . . . . . . . . . . & . & 2 & 4 & . & . & . & . & . & . & 1 & . & . & 1 & . \\
\hline - - var. ampliata (Ehr.) Cleve ...... & + & $\cdot$ & . & . & . & 1 & . & 1 & . & . & . & . & 2 & . \\
\hline - - var. capitata Mölder....... & . & . & . & . & . & . & . & . & . & . & . & . & . & + \\
\hline - ladogense (Cleve) Foged ..... & . & . & 1 & . & . & . & . & . & . & . & . & . & . & . \\
\hline - sp. (II : 3$) \ldots \ldots \ldots \ldots \ldots \ldots \ldots$ & . & . & . & . & 1 & . & . & . & . & . & . & . & 1 & . \\
\hline Nitzschia acuta Hantzsch.......... & . & . & . & 2 & 4 & 2 & . & 1 & 3 & 1 & 1 & . & 14 & + \\
\hline - amphibia Grun. ............ & . & + & 3 & 4 & 3 & . & 1 & 2 & . & 2 & 1 & 1 & 14 & + \\
\hline - angustata (W. Smith) Grun... & + & 1 & 2 & 5 & 5 & 4 & 1 & 2 & 4 & 2 & . & 2 & 25 & . \\
\hline - - var. acuta Grun. . & . & 3 & . & 1 & . & . & . & . & . & 1 & . & . & 2 & . \\
\hline - denticula Grun. ........ & + & . & . & . & . & . & . & . & . & . & . & . & . & . \\
\hline - dissipata (Kütz.) Grun.... & . & 1 & 3 & 1 & 1 & . & . & . & . & . & . & . & 2 & . \\
\hline - frustulum Kütz. ........... & . & 5 & 8 & . & . & . & 2 & . & . & . & . & . & 2 & . \\
\hline - - var. perpusilla (Rabh.) Grun. & . & . & 3 & . & . & . & . & . & 1 & . & 1 & . & 2 & . \\
\hline - gracilis Hantzsch... & . & . & . & . & 1 & . & . & . & . & . & . & . & 1 & . \\
\hline - kützingiana Hilse... & . & . & . & . & . & . & 1 & . & . & . & . & . & 1 & . \\
\hline - linearis W. Smith... & . & $\cdot$ & . & . & 2 & . & . & . & . & . & . & . & 2 & + \\
\hline - palea (Kütz.) W. Smith... & . & + & . & . & . & . & . & . & . & . & . & . & . & . \\
\hline - recta Hantzsch. ....... & $\cdot$ & . & . & 5 & 5 & 4 & 3 & 3 & 4 & 4 & 2 & 1 & 31 & + \\
\hline - sigmoidea (Ehr.) W. Smith..... & + & 8 & 1 & 5 & 5 & 4 & 3 & 1 & 4 & 5 & 4 & 2 & 33 & + \\
\hline - tryblionella Hantzsch var. debilis & & & & & & & & & & & & & & \\
\hline (Arnott) A. Mayer..... & . & $\cdot$ & . & . & 1 & . & . & . & . & . & . & . & 1 & . \\
\hline - hollerupensis nov. spec........ & . & . & . & . & 1 & . & 1 & 1 & . & . & . & . & 3 & - \\
\hline
\end{tabular}




\begin{tabular}{|c|c|c|c|c|c|c|c|c|c|c|c|c|c|c|}
\hline & \multirow[b]{2}{*}{ 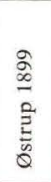 } & \multirow[b]{2}{*}{ 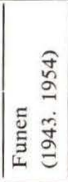 } & \multirow[b]{2}{*}{ 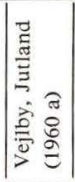 } & \multicolumn{10}{|c|}{ Hollerup } & \multirow[b]{2}{*}{$\frac{\grave{J}}{\bar{J}}$} \\
\hline & & & & $\begin{array}{l}n \\
1 \\
\dot{0} \\
z\end{array}$ & $\begin{array}{l}0 \\
1 \\
\dot{b} \\
\dot{0} \\
z\end{array}$ & $\begin{array}{l}\frac{n}{1} \\
= \\
\dot{0} \\
\dot{z}\end{array}$ & $\begin{array}{l}\infty \\
\stackrel{\infty}{1} \\
\underline{b} \\
\dot{0} \\
\grave{z}\end{array}$ & $\begin{array}{l}\text { तิ } \\
\stackrel{2}{ } \\
\dot{0} \\
\dot{0}\end{array}$ & $\begin{array}{l}\hat{ָ} \\
\tilde{d} \\
\vec{d} \\
\dot{0} \\
\dot{0}\end{array}$ & 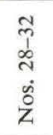 & $\begin{array}{l}\dot{0} \\
\tilde{m} \\
m \\
m \\
\dot{m} \\
\dot{0} \\
z\end{array}$ & 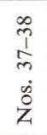 & 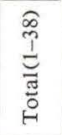 & \\
\hline Opephora martyi Hérib. ......... & + & 10 & 35 & 5 & 5 & 5 & 3 & 3 & 5 & 5 & 4 & 2 & 37 & + \\
\hline Pinnularia acrosphaeria Bréb. . . . . . . . & + & . & . & . & . & . & . & . & . & . & . & . & . & . \\
\hline 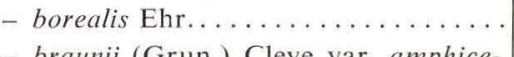 & . & 2 & 1 & . & . & . & . & . & . & 1 & 2 & . & 3 & . \\
\hline $\begin{array}{c}\text { - braunii (Grun.) Cleve var. amphice- } \\
\text { phala (A. Mayer) Hust. ........... }\end{array}$ & . & 2 & 1 & . & . & $\cdot$ & $\cdot$ & . & . & $\cdot$ & $\cdot$ & . & . & . \\
\hline 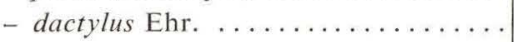 & . & . & 4 & . & . & . & . & . & . & . & . & . & . & . \\
\hline - divergens W. Smith .......... & . & . & 2 & . & . & . & . & . & . & . & 1 & 1 & 2 & . \\
\hline 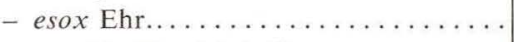 & . & . & $\cdot$ & . & . & . & 1 & . & . & . & . & . & 1 & . \\
\hline - gentilis (Donkin) Cleve........ & . & + & 2 & . & . & . & . & . & 1 & . & . & . & 1 & . \\
\hline- gibba Ehr................. & . & . & 2 & 3 & 2 & . & . & . & . & 2 & 1 & . & 8 & + \\
\hline - - var. linearis Hust. . . . . . . . . . . & . & 1 & $\cdot$ & . & . & . & . & . & . & . & . & . & . & . \\
\hline - interrupta W. Smith fo. minutissima & & & & & & & & & & & & & & \\
\hline Hust. . . . . . . . . . . & . & . & 1 & . & . & . & . & $\cdot$ & . & . & . & . & . & . \\
\hline - intermedia Lagerst. . . . .......... & . & . & . & . & . & . & . & . & . & . & 1 & . & 1 & . \\
\hline - krockii (Grun.) Hust. ...... & . & . & . & . & . & . & . & . & . & . & 1 & . & 1 & . \\
\hline - lata (Bréb.) W. Smith .... & . & . & 4 & . & . & . & . & . & . & . & . & . & . & . \\
\hline - legumen Ehr. ........... & + & . & . & 1 & . & . & . & . & . & . & . & . & 1 & . \\
\hline - maior Kütz. . . . . . . . . . . & + & 5 & 12 & 3 & 3 & 1 & 3 & . & . & 2 & 3 & 1 & 16 & + \\
\hline - mesolepta (Ehr.) W. Smith var. & & & & & & & & & & & & & & \\
\hline stauroneiformis Grun......... & + & $\cdot$ & . & $\cdot$ & . & . & . & $\cdot$ & . & . & 1 & . & 1 & . \\
\hline - microstauron (Ehr.) Cleve...... & . & . & . & . & . & . & . & . & . & . & . & . & . & + \\
\hline - - var. brébissonii (Kütz.) Hust...... & + & 2 & . & . & . & . & . & . & . & . & 1 & 1 & 2 & + \\
\hline - - - fo. diminuta Grun........ & . & . & 1 & . & . & . & . & . & . & . & . & . & . & . \\
\hline - nobilis Ehr............... & + & . & . & . & . & . & 1 & . & . & 1 & 2 & 1 & 5 & . \\
\hline - parva (Greg.) Cleve var. minuta & & & & & & & & & & & & & & \\
\hline Østrup $\ldots \ldots \ldots \ldots \ldots \ldots$ & . & . & $\cdot$ & . & . & . & . & . & . & . & 1 & . & 1 & . \\
\hline - stauroptera Grun. ..... & + & . & $\cdot$ & . & . & . & . & . & . & . & . & . & . & . \\
\hline - stomatophora Grun. ...... & . & . & . & . & . & . & . & . & . & 1 & . & . & 1 & . \\
\hline - streptoraphe Cleve....... & . & . & . & . & . & . & . & . & . & . & 1 & . & 1 & . \\
\hline - subsolaris (Grun.) Cleve..... . & . & . & . & 1 & 1 & . & . & . & . & 1 & . & . & 3 & . \\
\hline - viridis (Nitzsch) Ehr......... & + & 6 & 1 & 2 & 2 & 1 & 2 & . & . & 2 & 2 & 1 & 12 & + \\
\hline - - var. sudetica (Hilse) Hust. . & . & 1 & . & . & . & . & . & . & . & . & . & . & . & . \\
\hline Rhoicosphenia curvata (Kütz.) Grun... & + & 8 & 22 & 5 & 4 & 4 & 3 & 2 & 4 & 5 & 4 & 2 & 33 & + \\
\hline Rhopalodia gibba (Ehr.) O. Müller .... & . & 9 & 26 & 5 & 5 & 4 & 2 & 4 & 5 & 5 & 4 & 2 & 36 & + \\
\hline - - var. ventricosa (Ehr.) Grun....... & + & 3 & + & 4 & 5 & 4 & 2 & 2 & 4 & 5 & 4 & 1 & 31 & + \\
\hline - parallela (Grun.) O. Müller... & . & + & . & . & . & . & . & . & . & . & . & . & . & . \\
\hline Stauroneis acuta W. Smith..... & + & 3 & . & 2 & 3 & 1 & 1 & . & . & 3 & 1 & . & 11 & . \\
\hline - acutiuscula M. Perag. \& Hérib...... & + & . & . & . & . & . & . & . & . & . & . & . & . & . \\
\hline - anceps Ehr........... & . & 1 & 1 & . & 3 & . & . & . & 1 & . & . & . & 4 & + \\
\hline - - fo. gracilis (Ehr.) Cleve. & . & . & 2 & . & . & . & . & 1 & . & 1 & . & . & 2 & . \\
\hline - - var. hyalina Brun \& Perag. & . & . & 5 & . & . & 1 & . & 1 & . & 1 & . & . & 3 & - \\
\hline - dilatata W. Smith . . & + & $\cdot$ & $\cdot$ & $\cdot$ & . & . & . & . & $\cdot$ & . & $\cdot$ & . & . & . \\
\hline - parvula Grun.......... & + & . & 2 & . & . & . & . & . & . & . & $\cdot$ & . & . & . \\
\hline - nathorstii nov. spec. . . . . . . & . & . & . & . & . & . & . & . & . & 1 & . & . & 1 & - \\
\hline
\end{tabular}




\begin{tabular}{|c|c|c|c|c|c|c|c|c|c|c|c|c|c|c|}
\hline & & & & & & & & $\mathrm{Hol}$ & llerup & & & & & \\
\hline & 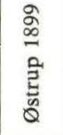 & 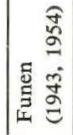 & 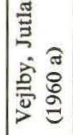 & $\begin{array}{l}n \\
1 \\
\dot{0} \\
z \\
z\end{array}$ & $\begin{array}{l}0 \\
1 \\
b \\
0 \\
0 \\
z\end{array}$ & $\begin{array}{l}\stackrel{2}{1} \\
\stackrel{1}{=} \\
\dot{0} \\
\dot{z}\end{array}$ & $\begin{array}{l}\infty \\
\overrightarrow{1} \\
\underline{\sigma} \\
\dot{0} \\
\stackrel{0}{z}\end{array}$ & 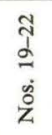 & $\begin{array}{l}\hat{T} \\
\tilde{N} \\
\tilde{N} \\
\dot{0} \\
\dot{z}\end{array}$ & 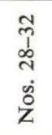 & $\begin{array}{l}0 \\
i \\
m \\
\dot{0} \\
\dot{z}\end{array}$ & $\begin{array}{c}\infty \\
0 \\
0 \\
m \\
m \\
0 \\
0 \\
z\end{array}$ & 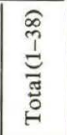 & $\frac{\overrightarrow{0}}{\overrightarrow{0}}$ \\
\hline Stauroneis phoenicenteron Ehr. ....... & + & 5 & 2 & 2 & 1 & 1 & 2 & . & 4 & 3 & 4 & . & 17 & + \\
\hline - kriegeri Patrick .............. & . & . & . & . & 1 & . & . & . & . & . & . & . & 1 & . \\
\hline - smithii Grun............ & + & . & . & . & . & . & . & . & . & . & . & . & . & . \\
\hline - - var. incisa Pant........... & . & . & . & 1 & . & . & . & . & . & . & . & . & 1 & . \\
\hline - thermicola (Boye Petersen) Lund ... & . & . & . & . & . & 1 & 1 & 1 & . & 2 & 2 & . & 7 & . \\
\hline Stephanodiscus astraea (Ehr.) Grun... . & + & + & 19 & 5 & 5 & 5 & 3 & 4 & 5 & 5 & 4 & 2 & 38 & . \\
\hline - - var. minutula (Kütz.) Grun....... & . & 9 & 32 & 5 & 3 & 5 & 3 & 4 & 4 & 3 & 3 & 2 & 32 & + \\
\hline - dubius (Fricke) Hust. . . . . . . . . . & . & + & . & 4 & 5 & 2 & 2 & 3 & 5 & 5 & 2 & 1 & 29 & + \\
\hline - hantzschii Grun.......... & . & 2 & 8 & 5 & 4 & 1 & . & 1 & 3 & 1 & 3 & . & 18 & + \\
\hline - niagarae Ehr. .......... & + & 10 & 32 & . & . & . & . & . & . & . & 2 & 1 & 3 & . \\
\hline Surirella angusta Kütz............ & . & + & 1 & . & . & . & . & . & . & . & . & . & . & . \\
\hline - birostrata Hust. ........ & . & . & . & . & 1 & . & . & . & . & . & . & . & 1 & . \\
\hline - biseriata Bréb. ........ & . & . & . & . & 2 & . & . & . & . & . & . & . & 2 & . \\
\hline - - var. bifrons (Ehr.) Hust... & + & + & . & . & . & . & . & . & . & . & . & . & . & . \\
\hline - - - fo. punctata Meister... & . & 3 & . & . & 3 & 1 & 1 & . & 1 & . & 1 & 2 & 9 & . \\
\hline - gracilis (W. Smith) Grun.......... & . & . & . & . & 1 & . & . & . & . & . & . & . & 1 & . \\
\hline - linearis W. Smith............... & . & . & . & 3 & 3 & . & . & 1 & . & . & . & . & 7 & . \\
\hline - - var. constricta (Ehr.) Grun. & + & 1 & . & 2 & 3 & . & 1 & . & . & . & . & 1 & 7 & . \\
\hline - - var helvetica (Brun.) Meister .... & . & 4 & . & 3 & 4 & . & 2 & . & 1 & 1 & . & . & 11 & + \\
\hline - ovalis Bréb............ & . & . & + & . & . & . & . & . & . & . & . & . & . & . \\
\hline - ovata Kütz............... & + & . & 10 & 1 & . & . & . & . & . & . & . & . & 1 & . \\
\hline - robusta Ehr. ............. & . & 2 & . & . & 3 & 1 & . & . & 1 & 1 & 2 & 1 & 9 & . \\
\hline - - var. splendida (Ehr.) van Heurck & . & + & . & . & . & . & . & . & . & . & . & . & . & . \\
\hline - - - fo. punctata Hust. ..... & . & . & . & 2 & . & . & . & . & . & . & . & . & 2 & . \\
\hline - tenera Greg.............. & + & . & . & 1 & . & . & . & . & . & . & . & . & 1 & . \\
\hline - - var. nervosa Mayer... & . & . & . & 1 & 1 & 1 & . & . & . & . & . & . & 3 & . \\
\hline Synedra acus Kütz....... & + & + & - & . & 1 & . & . & . & . & . & . & . & 1 & . \\
\hline - capitata Ehr............ & + & 9 & . & 3 & 5 & 4 & 1 & 3 & 4 & 4 & . & 1 & 25 & + \\
\hline - parasitica W. Smith. ...... & + & 8 & 2 & 5 & 5 & 3 & 1 & 2 & 4 & 1 & 4 & 2 & 27 & + \\
\hline - - var. subconstricta Grun..... & . & 2 & . & 2 & 2 & . & . & 1 & 1 & 1 & 4 & 1 & 12 & + \\
\hline - pulchella Kütz.......... & + & . & 1 & . & . & . & . & . & . & . & 1 & . & 1 & . \\
\hline - tabulata (Ag.) Kütz. . . & . & 1 & . & 1 & 2 & . & 1 & 1 & . & 1 & . & 1 & 7 & 4 \\
\hline - ulna (Nitzsch) Ehr. ..... & + & 9 & 32 & 5 & 4 & 4 & 3 & 4 & 5 & 4 & 4 & 2 & 35 & + \\
\hline - - var. aequalis (Kütz.) Hust.. . & + & 8 & 3 & 5 & 5 & 3 & 3 & 2 & 3 & 3 & 1 & 2 & 27 & + \\
\hline _ - var. biceps Kütz. ....... & . & 6 & - & 1 & 3 & . & . & . & . & 2 & 1 & . & 7 & + \\
\hline - - var. danica (Kütz.) Grun... & . & 6 & 4 & 4 & . & 2 & 2 & 2 & 1 & 3 & 1 & . & 15 & . \\
\hline - - spatulifera Grun.... & . & . & . & . & . & 2 & . & . & 1 & . & . & . & 3 & . \\
\hline - vaucheriae Kütz. ...... & . & & . & . & . & . & . & . & . & . & . & . & . & . \\
\hline Tabellaria fenestrata (Lyngb.) Kütz... . & + & + & 11 & . & 2 & . & 1 & . & 1 & 1 & 1 & . & 6 & + \\
\hline - - flocculosa (Roth) Kütz.......... & . & 2 & 4 & 3 & 1 & 1 & . & . & . & . & . & . & 5 & . \\
\hline Tetracyclus emarginatus W. Smith .... & + & 4 & 32 & . & . & $\cdot$ & . & . & . & . & . & . & . & - \\
\hline - lacustris Ralfs........ & . & . & 17 & . & . & . & . & . & . & . & 1 & . & 1 & - \\
\hline - - var. strumosa (Ehr.) Hust. . & ${ }^{\circ}$ & 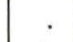 & 3 & . & . & . & . & . & . & . & . & . & . & . \\
\hline Østrupia zachariasi (Reich.) Hust. .... & + & + & . & 1 & 1 & . & . & . & . & . & . & . & 2 & . \\
\hline Number of forms (total) ... & 157 & 222 & 236 & 209 & 224 & 156 & 169 & 132 & 160 & 197 & 208 & 126 & 355 & 158 \\
\hline
\end{tabular}




\section{LITERATURE}

Brockmann, C., 1950: Die Watt-Diatomeen der schleswig-holsteinischen Westküste. Abh. Senkenb. Naturf. Ges. Abh. 478. Frankfurt am Main.

Cleve, P. T., 1894-95: Synopsis of the Naviculoid Diatoms. I, II. - K. Sv. Vet.-Akad. Handl. Bd. 26, N:o 2; Bd. 27, N:o 3. Stockh.

Cleve-Euler, A., 1932: Die Kieselalgen des Tåkernsees in Schweden. - K. Sv. Vet.Akad. Handl. 3. Ser. Bd. 11, No. 2. Stockh.

- 1953 a: Die Diatomeen von Schweden und Finnland. II. - K. Sv. Vet.-Akad. Handl. 4. Ser. Bd. 2, No. 1. Stockh.

- 1953 b: Die Diatomeen von Schweden und Finnland. III. - Ibid. Bd. 4, No. 5. Stockh.

- 1955: Die Diatomeen von Schweden und Finnland. IV. - Ibid. Bd. 5, No. 4. Stockh.

Foged, N., 1953: Diatoms from West-Greenland. - Medd. Grønl. 147 : 10. København.

- 1954 a: On the Diatom Flora of Some Funen Lakes. - Fol. Limnol. Scand. 6. København.

- 1954 b: En interglacial diatomejordaflejring i Øst-Fyn. (English summary). - Medd. Da. Geol. For. 12. København.

- 1955: Diatoms from Peary Land, North Greenland. - Medd. Grønl. 128: 7. København.

- 1957: Diatoms from Rennell Island, British Solomon Islands. - The Natural History of Rennell Island, British Solomon Islands. Vol. 3. København.

- 1958: The Diatoms in the Basalt Area and Adjoining Areas of Archean Rock in West Greenland. - Medd. Grønl. $156: 4$. København.

- 1959: Diatoms from Afghanistan. - Biol. Skr. Kgl. Da. Vid. Selsk. 11 : 1. København.

- 1960 a: Diatomefloraen i en interglacial kiselguraflejring ved Rands fjord i Østjylland. (English summary.) - Medd. Da. Geol. For. 14 : 3. København.

- $1960 \mathrm{~b}$ : Observation of the Freshwater Diatom Flora in the Neighbourhood of Tromsø in North Norway. - Acta Borealia. A. Scientia, no. 16. Tromsø.

- 1960 c: Notes on Diatoms I-II. - Bot. Tidsskr. 55. København.

- 1962:Freshwater Diatoms from Spitsbergen. (in press.)

Hartz, N. \& E. Østrup, 1899: Danske Diatomejordaflejringer. - Danm. Geol. Unders. II R. Nr. 9. København.

Hustedt, F., 1927: Fossile Bacillariaceen aus dem Loa-Becken in der Atacama-Wüste, Chile. - Arch. Hydrobiol. 18. Stuttgart.

- 1930: Bacillariophyta (Diatomeae). - A. Pascher: Die Süsswasser-Flora Mitteleuropas. 10. Jena.

- 1930-37: Die Kieselalgen Deutschlands, Österreichs und der Schweiz etc. I-II. L. Rabenhorst's Kryptogamen-Flora, Bd. VII, Teil 1 und Teil 2, Lieferung 1-5. Leipzig.

- 1937-39: Systematische und ökologische Untersuchungen über die Diatomeenflora von Java, Bali und Sumatra. - Arch. Hydrobiol. Suppl. 15, 16. Stuttgart.

- 1944: Neue und wenig bekannte Diatomeen. - Ber. deutsch. bot. Ges. 61 : 5 . Berlin.

- 1945: Diatomeen aus Seen und Quellgebieten der Balkan-Halbinsel. - Arch. Hydrobiol. $40: 4$. Stuttgart.

- 1948: Die Diatomeenflora diluvialer Sedimente bei dem Dorfe Gaj bei Konin im Warthegebiet. - Schweiz. Zeitschr. Hydrol. 11. Zürich. 
Hustedt, F., 1949: Süsswasser-Diatomeen aus dem Albert-Nationalpark in BelgischKongo. - Expl. Parc Nat. Albert, Miss. H. Damas (1935-1936). 8. Bruxelles.

- 1950: Die Diatomeenflora norddeutscher Seen mit besonderer Berüchsichtigung des holsteinischen Seengebiets. - Arch. Hydrobiol. 43. Stuttgart.

- 1953 : Diatomeen aus dem Naturschutzgebiet Seeon.-Arch. Hydrobiol. 47 : 4. Stuttgart.

- 1954 a: Die Diatomeenflora des Interglazials von Oberohe in der Lüneburger Heide. - Abh. Naturw. Ver. Bremen. 33 : 3. Bremen.

- 1954 b: Die Diatomeenflora der Eifelmaare. - Arch. Hydrobiol. 48 : 4. Stuttgart.

- 1954 c: Neue und wenig bekannte Diatomeen. VII. - Ber. Deut. Bot. Ges. 58 : 3. Berlin.

- 1955 a: Marine Littoral Diatoms of Beaufort, North Carolina. - Duke Univ. Mar. Stat. 6. Durham, North Carolina.

- 1955 b: Neue und wenig bekannte Diatomeen. VIII. - Abh. Naturw. Ver. Bremen $34: 1$.

- 1957: Die Diatomeenflora des Flusssystems der Weser im Gebiet der Hansestadt Bremen. - Abh. Naturw. Ver. Bremen. $34: 3$.

- 1959 a: Die Diatomeenflora der Unterweser von der Lesummündung bis Bremerhaven etc. - Veröff. Inst. Meeresforsch. Bremerhaven. 6.

- 1959 b: Die Kieselalgen Deutschlands etc. in Rabenhorst's Kryptogamen-Flora VII. Band. 2. Teil. Lieferung 6. Leipzig.

Krasske, G., 1929: Beiträge zur Kenntnis der Diatomeenflora Sachsens. - Bot. Arch. $27: 3 / 4$.

- 1933: Diatomeen aus dem Oberpliocän von Willershausen. - Arch. Hydrobiol. 24. Stuttgart.

- 1938: Beiträge zur Kenntnis der Diatomeen-Vegetation von Island und Spitzbergen. - Arch. Hydrobiol. 33. Stuttgart.

Lund, J.W. G., 1946: Observations on Soil Algae. I. The Ecology, Size and Taxonomy of British Soil Diatoms. - The New Phytologist. $45: 1$. London.

MAYer, A., 1919: Bacillariales von Reichenhall und Umgebung. - Krypt. Forsch. 1: 4.

Mills, F. WM., 1933-1934: An Index to the Genera and Species of the Diatomaceae and Their Synonyms. 1816-1932. London.

MøLler, M., 1943: Lundeborg Diatomejordleje. - Af Fyns Flora og Fauna. 1. Odense.

Okuno, H., 1952: Atlas of Fossil Diatoms From Japanese Diatomite Deposits. - Tokyo.

Petersen, J. Boye, 1915: Studier over danske aërofile Alger. - Kgl. Da. Vid. Selsk. Skr. 7. Række. Naturv. og mathem. Afd. $12: 7$. København.

- 1928: The Aërial Algæ of Iceland. - The Botany of Iceland. 2. København.

Reimer, C.W., 1959: Some New United States Distribution Records for the Diatom Genus Navicula (Bacillariophyceae). - Proc. Acad. Nat. Sci. Philad. 111. Philadelphia.

Ross, R., 1947: Freshwater Diatomeae. - In N. Polunin: Botany of the Canadian Eastern Arctic. II.

Sснмidt, A., 1874-1944: Atlas der Diatomaceenkunde. Aschersleben - Leipzig.

Schulz, P., 1926: Die Kieselalgen der Danziger Bucht mit Einschluss derjenigen aus glazialen und postglazialen Sedimenten. - Bot. Arch. 13 : 1. Königsberg.

Østrup, E., 1910: Danske Diatoméer. København.

- 1918: Fresh-Water Diatoms From Iceland. - The Botany of Iceland. II. København. 
PLATES 


\section{PLATE I}

1,2. Eunotia sudetica $\mathrm{O}$. Müller

3. Achnanthes dispar Cleve

4. Achnanthes kolbei Hustedt

5. Achnanthes exigua Grun.

6, 7. Achnanthes lanceolata (Breb.) Grun. var. rostrata (Østrup) Hustedt

8. Achnanthes lanceolata var. elliptica Cleve

9. Cocconeis thumensis A. Mayer

10. Achnanthes daui nov. spec.

11. Caloneis bacillum (Grun.) Cleve fo. inflata Hustedt

12, 13. Caloneis bacillum var. lancettula (Schulz) Hustedt

14. Caloneis silicula (Ehr.) Cleve var. ventricosa Cleve

15. Caloneis bacillum var. lancettula forma.

16. Caloneis bacillum forma.

(Scale $10 \mu$ ) 
Plate I
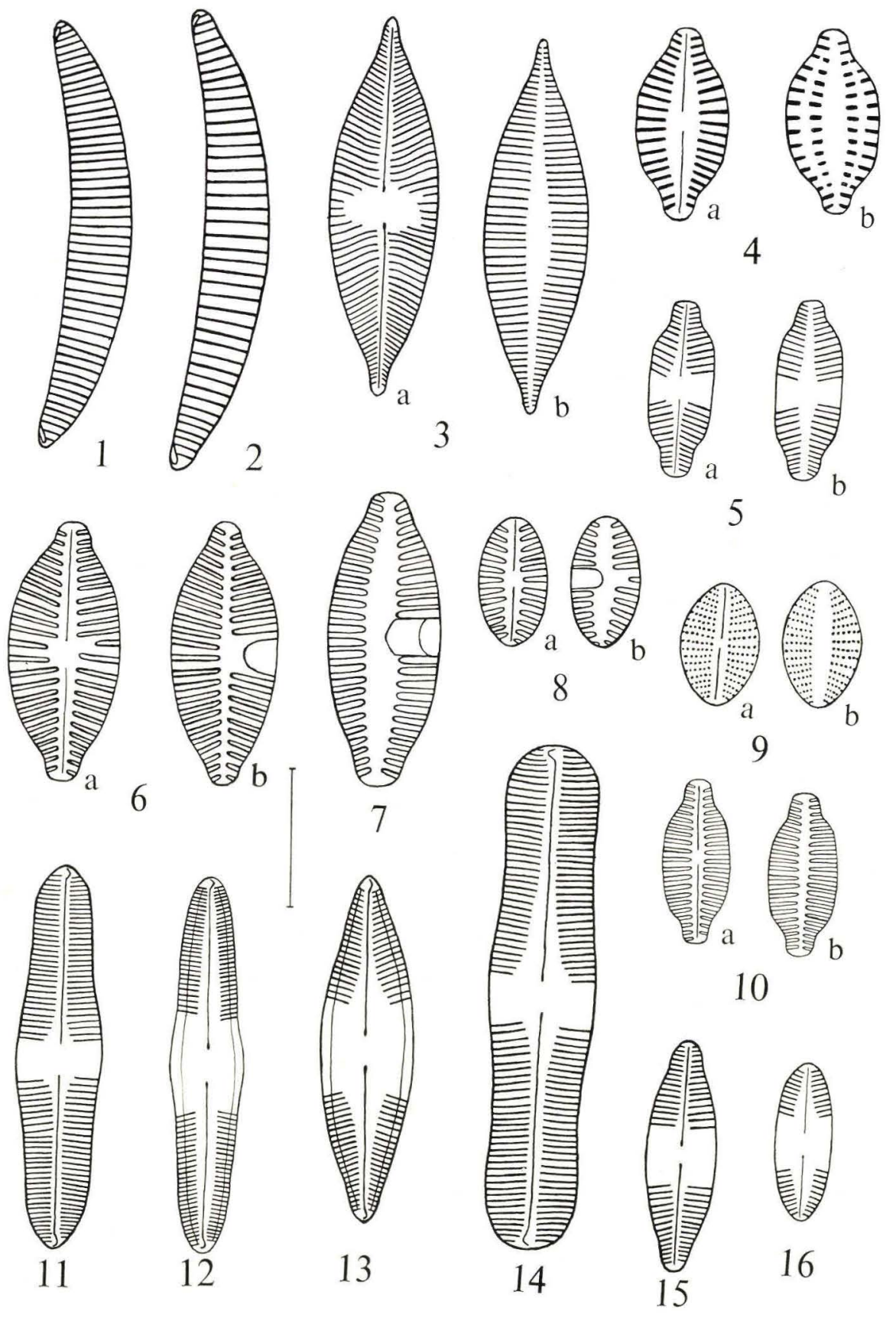


\title{
PLATE II
}

\author{
1. Østrupia zachariasi (Reichelt) Hustedt \\ 2. Stauroneis nathorstii nov. spec. \\ 3. Neidium $\mathrm{sp}$. \\ 4. Navicula menisculus Schum. \\ 5. Navicula hartzii nov. spec. \\ 6. Diploneis oculata (Bréb.) Cleve \\ 7. Navicula mentzii nov. spec. \\ 8. Navicula placentula (Ehr.) Grun. fo. rostrata A. Mayer \\ 9. Navicula placentula var. jenisseyensis (Grun.) Meister \\ 10. Navicula meniscoides Hustedt.? \\ 11. Navicula rotunda Hustedt \\ 12. Navicula modica Hustedt
}

$($ Scale $10 \mu)$ 


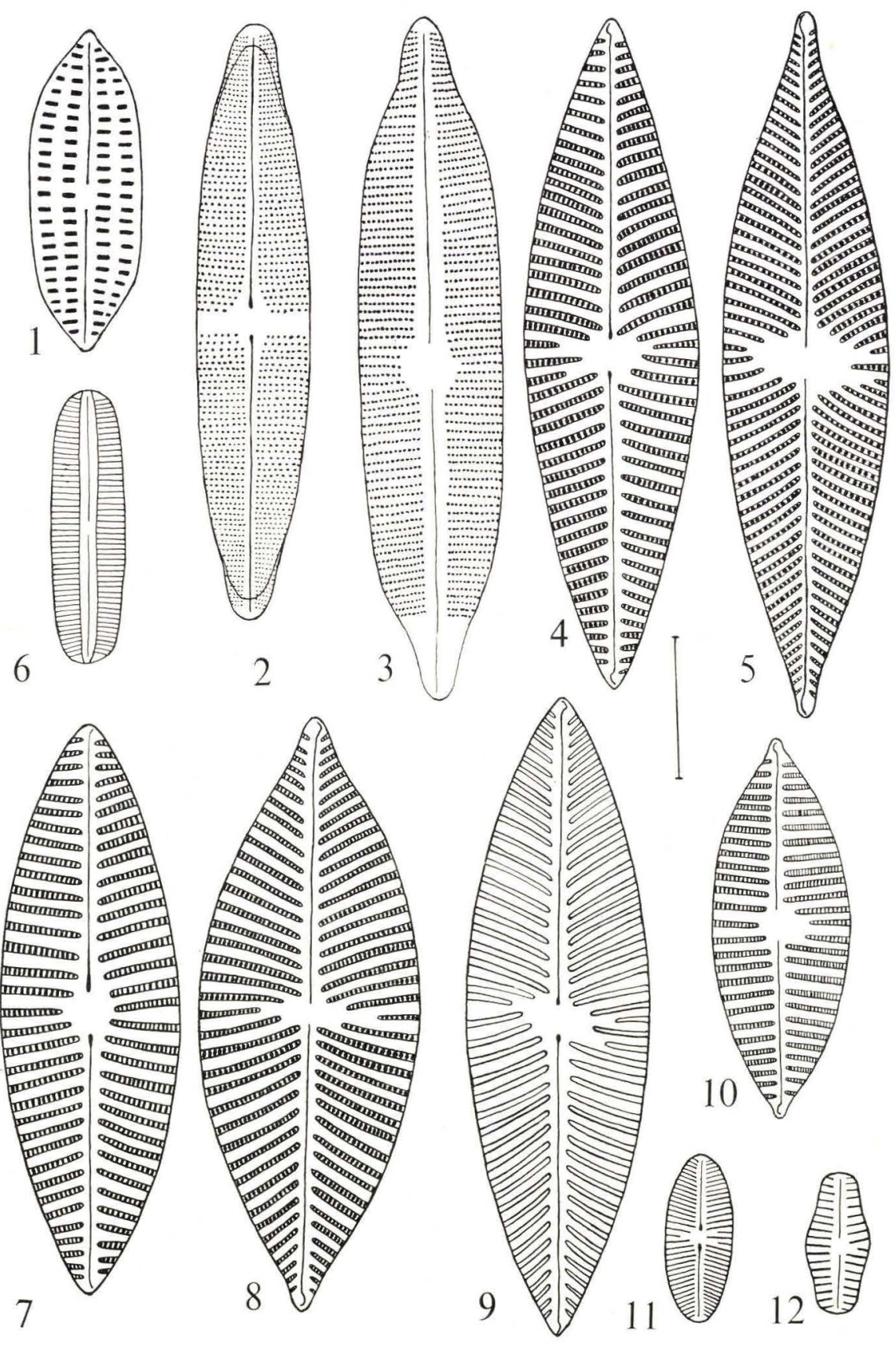




\section{PLATE III}

1. Navicula placentula fo. jenisseyensis (Grun.) Meister

2. Navicula clementis Grun.

3, 6. Navicula exigua (Greg.) O. Müller var. signata Hustedt

4, 5. Navicula hungarica Grun.

7. Navicula $\mathrm{sp}$.

8. Navicula hungarica Grun. var. lüneburgensis Grun.

9. Navicula costulata Grun.

10, 11. Navicula graciloides A. Mayer

12. Navicula diversistriata Hustedt. (?).

13. Navicula cincta (Ehr.) Kütz. var. heufleri Grun.

14. Navicula jessenii nov. spec.

(Scale $10 \mu$ ) 


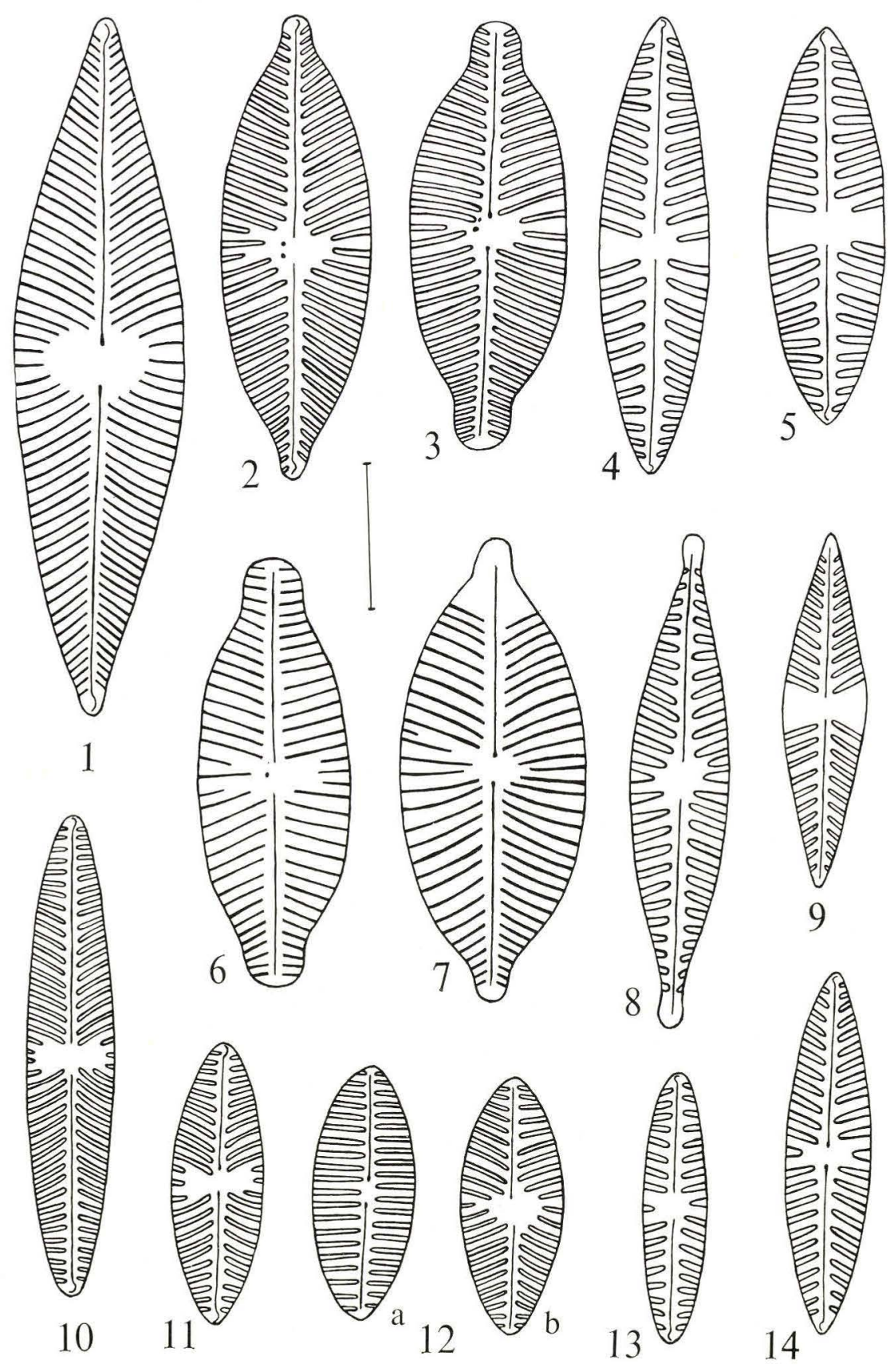




\section{PLATE IV}

1. Navicula pupula Kütz. var. hollerupensis nov. var.

2. Navicula laterostrata Hustedt

3, 4. Navicula bacillum Hustedt

5. Navicula rotunda Hustedt

6. Navicula interglacialis Hustedt

7. Navicula jentzschii Grun.

8. Stauroneis thermicola (Boye Petersen) Lund

9. Navicula hollerupensis nov. spec.

10. Navicula hustedti Krasske var. obtusa Hustedt

11. Navicula iversenii nov. spec.

12. Navicula acceptata Hustedt.?.

13. Navicula sp.

14. Navicula paludosa Hustedt

15. Navicula schönfeldii Hustedt

16. Navicula vitabunda Hustedt

17. Navicula hungarica var. lüneburgensis Grun. (?).

18. Navicula milthersii nov. spec.

19. Navicula rotunda Hustedt

20. Navicula excelsa Krasske

21. Navicula vaupellii nov. spec.

22. Navicula warmingii nov. spec.

23. Navicula schadei Krasske

24. Navicula similis Krasske

(Scale $10 \mu)$ 


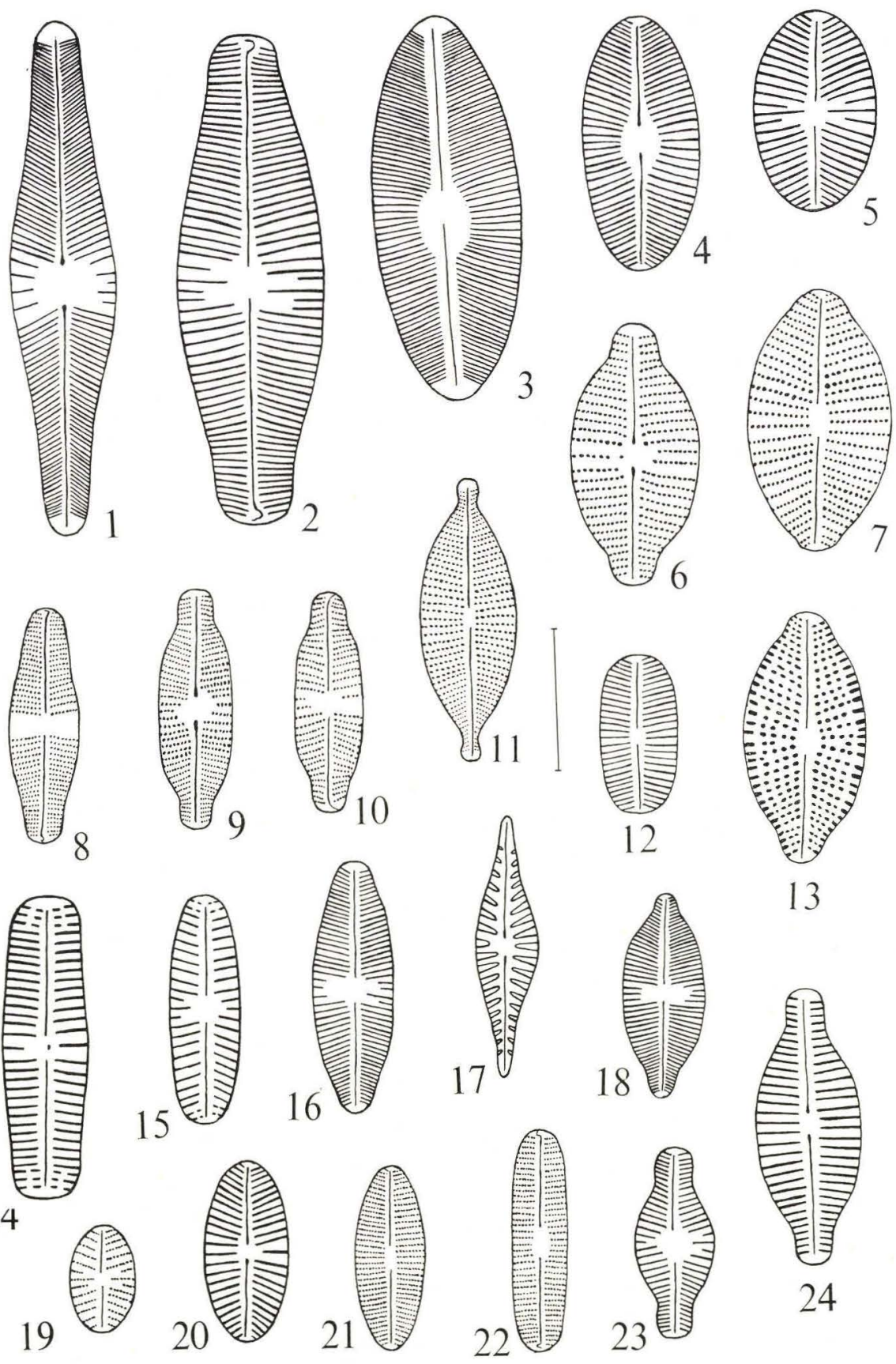




\section{PLATE V}

1. Pinnularia lenticula A. Cleve-Euler var. brevistriata A. Cleve-Euler

2. Pinnularia microstauron (Ehr.) Cleve var. ambigua Meister

3. Pinnularia karelica Cleve

4. Pinnularia intermedia Lagerst.

5. Pinnularia lagerstedti (Cleve) Hustedt

6. Gomphonema abbreviatum Ag. ?. Kütz. forma.

7. Gomphonema intricatum Kütz. var. pumila Grun.

8. Forma between G. acuminatum Ehr. and G. augur Ehr.

9. Nitzschia hollerupensis nov. spec.

10. Gomphocymbella ancyli (Cleve) Hustedt

11. Amphora ovalis Kütz. var. libyca (Ehr.) Cleve

12. Gomphonema gracile Ehr.

13. Amphora triundulata Ross

14. Cymbellonitzschia diluviana Hustedt

15. Cymbella thumensis (A. Mayer) Hustedt

(Scale $10 \mu$ ) 
Plate V

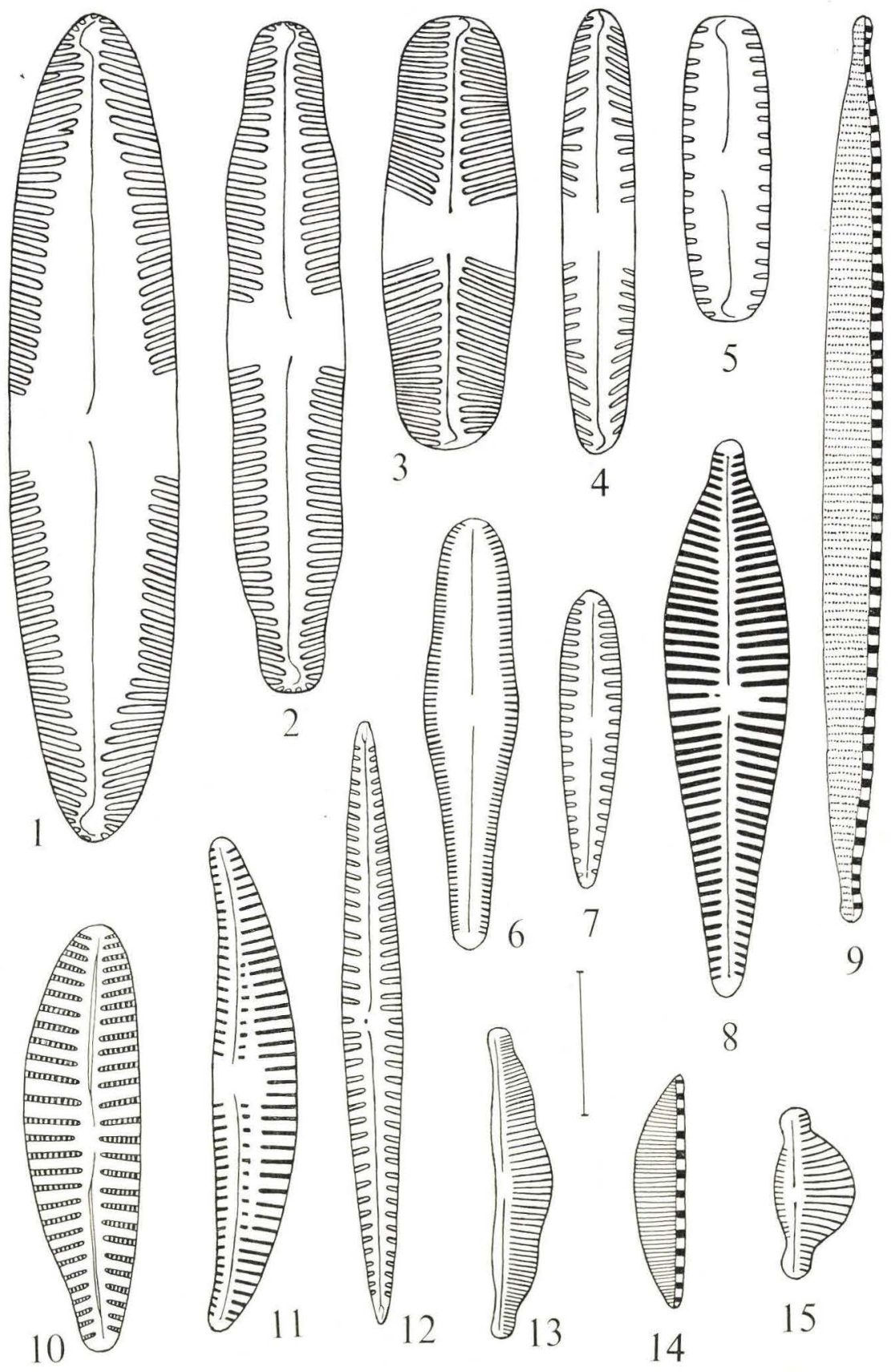


